\title{
EQUILIBRIUM RELATIONSHIPS BETWEEN THERMAL BARRIER OXIDES AND SILICATE MELTS
}

\author{
David L. Poerschke ${ }^{\mathrm{a}}$, Talia L. Barth ${ }^{\mathrm{b}}$, Carlos G. Levi \\ Materials Department, University of California, Santa Barbara, CA 93106-5050
}

\begin{abstract}
The phase equilibria between thermal barrier coating (TBC) materials and calcium-magnesiumaluminosilicate melts (CMAS, representing deposits formed when siliceous debris is ingested into modern turbine engines), were investigated at $1300^{\circ} \mathrm{C}$. The primary goal was to understand the influence of the deposit and thermal barrier oxide compositions on the melt solubility limits and reaction product constitution. Model deposit compositions with $\mathrm{SiO}_{2}$ to $\mathrm{CaO}$ ratios from 1.4 to 4.7 and with or without $\mathrm{MgO}$ were reacted with yttria- and gadolinia-zirconia thermal barrier oxides ranging from pure $\mathrm{ZrO}_{2}$ to the pure yttria and gadolinia. The reactions formed various crystalline silicate phases; rare earth-calcium-silicate apatite and zircon $\left(\mathrm{ZrSiO}_{4}\right)$ were observed most frequently. Following the reactions, the residual melts were depleted in $\mathrm{SiO}_{2}$ and generally enriched in $\mathrm{CaO}, \mathrm{MgO}$, and $\mathrm{Al}_{2} \underline{\mathrm{O}}_{3}$. The implications of the anticipated changes in the melt viscosity and the cation partitioning between the melt and various solid solution phases on the efficacy of degradation-mitigating crystallization reactions are discussed.
\end{abstract}

Keywords: Thermal barrier coatings (TBC); Rare earth; Phase equilibria; CMAS; Solid solution

a Author to whom correspondence should be addressed: poerschke@engr.ucsb.edu.

b Present address: Department of Materials Science and Engineering, University of Michigan, Ann Arbor, MI

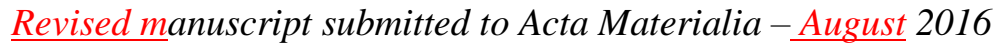

(C) 2016. This manuscript version is made available under the Elsevier user license http://www.elsevier.com/open-access/userlicense/1.0/ 


\section{INTRODUCTION}

Modern turbine engines employ thermal barrier coatings (TBC) to protect metallic structures in the hot section. Increased operating temperatures have expanded the menu of failure mechanisms impacting the durability of these ceramic coatings [1, 2]. Several failure modes involve interaction between the coatings and molten deposits that arise when siliceous debris (volcanic ash, sand, dust) ingested into the engine adhere to hot gas path components and impregnate their TBCs. These deposits are generically termed 'CMAS' owing to their basis in the $\mathrm{CaO}-\mathrm{MgO}-\mathrm{AlO}_{1.5}{ }^{\mathrm{c}}-\mathrm{SiO}_{2}$ system. The deposit compositions, which may also include $\mathrm{NaO}_{0.5}$, $\mathrm{KO}_{0.5}, \mathrm{FeO}_{\mathrm{x}}, \mathrm{TiO}_{2}$, etc vary regionally based on the geological sources and_wear of upstream components $[2,3]$. These composition variations make this degradation mode (and selection of an effective mitigation strategy) particularly complex because a coating material/architecture may exhibit drastically different behavior depending on the nature of the deposit.

Reactions with the deposit reduce the stability/adherence of the TBC as the melt wicks into the coating porosity, where it solidifies. Upon thermal cycling, the reduced in-plane compliance of the infiltrated layer increases thermal misfit stresses leading to premature coating failure. Thermomechanical analysis suggests that the stored elastic strain energy available to drive coating delamination/spallation increases nonlinearly with the depth of penetration [2, 4, 5]. To improve the coating durability following in-service CMAS deposition, mitigation strategies aim to minimize the depth of melt penetration by modifying the coating composition (to promote melt crystallization) or microstructure (to slow infiltration).

The melt crystallization behavior is determined by multi-component phase equilibria acting in concert with local temperature gradients. In the absence of coating/melt interaction the melt may crystallize if it drops significantly below its liquidus while infiltrating against the thermal gradient. These reactions are hereafter termed 'intrinsic' crystallization as they involve only oxides from the deposit; typical crystallization products are summarized in Table 1.

Alternatively, $\underline{\mathrm{TBC}}$ dissolution into the melt may promote the crystallization of phases containing constituents from both the coating and deposit. This pathway, termed 'reactive' crystallization, has been the focus of efforts to develop thermal barrier oxides (TBOs) with improved resistance to degradation by silicate deposits. It is desired to maximize the ratio of the volume crystallized $\left(\mathrm{V}_{\text {crys }}\right)$ per volume of dissolved coating $\left(\mathrm{V}_{\mathrm{TBO}}\right)$, as long as the crystallization

For convenience in interpreting molar concentrations, all oxides are represented in terms of single cation formula units. When appropriate, compact notation using the first letter of the cation symbol is employed (e.g. $\mathrm{C}=\mathrm{CaO}, \mathrm{A}=\mathrm{AlO}_{1.5} \mathrm{~S}=\mathrm{SiO}_{2}$, etc). 
reactions occur on a timescale faster than infiltration. This behavior is exemplified by rare earth (RE) zirconate pyrochlores (e.g. $\mathrm{Gd}_{2} \mathrm{Zr}_{2} \mathrm{O}_{7}$ [6]). Within tens of seconds [2] the $\mathrm{REO}_{1.5}$ reacts with $\mathrm{SiO}_{2}$ and $\mathrm{CaO}$ from the melt to crystallize a silicate with the oxyapatite structure, nominally $(\mathrm{RE}, \mathrm{Ca}, \mathrm{Zr})_{10}\left(\mathrm{SiO}_{4}\right)_{6} \mathrm{O}_{2}[6]$. Excess $\mathrm{ZrO}_{2}$ concomitantly 'reprecipitates' as a $\mathrm{REO}_{1.5}$-depleted cubic (fluorite) or tetragonal $\mathrm{ZrO}_{2}$ phase_[7]. The consumption of $\mathrm{SiO}_{2}$ and $\mathrm{CaO}$ from the melt via apatite crystallization may trigger subsequent intrinsic crystallization processes. Apatite and fluorite have been observed as initial reaction products for $\mathrm{Gd}_{2} \mathrm{Zr}_{2} \mathrm{O}_{7}$ exposed to a variety of deposit compositions $[6,8,9]$.

Not all rare earth-zirconia TBOs behave the same way. Some coatings (e.g., yttria stabilized zirconia, YSZ) do not contain enough $\mathrm{REO}_{1.5}$ to saturate the melt and precipitate apatite. Similarly, coatings with smaller RE cations (e.g. Yb, Y) favor crystallization of slowergrowing silicates such as garnet [7, 10] or cuspidine [11] (Table 1) rather than apatite. Additionally, the ratio $\mathrm{V}_{\text {crys }}: \mathrm{V}_{\text {TBO }}$ for a given reaction depends on the TBO solubility in the melt and the partitioning between the crystalline silicate(s) and reprecipitated fluorite [7, 12]. $\underline{\text { Studies }}$ on the behavior of YSZ coatings indicate that these processes are sensitive to the composition of the deposit. When exposed to silica-lean melts, $\underline{\mathrm{YSZ}}$ dissolves and reprecipitates $\mathrm{YO}_{1.5}$-depleted tetragonal $\mathrm{ZrO}_{2}$ that transforms to monoclinic $\mathrm{ZrO}_{2}$ upon cooling_[13]. Deposits with higher silica content react with YSZ to form $\mathrm{ZrSiO}_{4}[4,14]$ or $\mathrm{Ca}_{2}(\mathrm{ZrY}) \mathrm{Si}_{4} \mathrm{O}_{12}$ [15]. Although these phases yield a high $\mathrm{V}_{\text {crys }}: \mathrm{V}_{\mathrm{TBO}}$, they do not effectively block melt infiltration, presumably due to unfavorable crystallization kinetics or morphology.

The cumulative evidence indicates that the effectiveness of crystallization reactions to mitigate TBC degradation depends on both the TBO identity and the composition of the deposit. Efforts are currently underway to develop integrated, science-based understanding of the process with models to efficiently predict and optimize coating behavior upon exposure to a variety of deposits. This development has focused on characterizing the melting/crystallization behavior of relevant deposits [16], investigating and modeling the infiltration and failure behavior under thermal gradients [4], and elucidating the phase equilibria in key ternary subsystems [17] to support the development of thermodynamic databases. The further development of these databases to enable integration with thermomechanical models is hindered by a lack of data regarding the phase equilibria in higher-order systems (e.g. quinary/senary CMAS+TBO mixtures). This investigation is motivated by the need to identify relevant trends in reaction behavior and generate a dataset to benchmark new thermodynamic databases. 
This study systematically investigates the equilibrium phases resulting from reactions between a range of silicate melts and candidate TBOs (or their constituents) under conditions relevant to the early-stage deposit-TBC interactions. Emphasis is placed on elucidating the interplay between the $\mathrm{Si}$ :Ca ratio and presence of $\mathrm{MgO}$ in the initial silicate deposit as well as the $\mathrm{RE}: \mathrm{Zr}$ ratio in the $\mathrm{TBO}$ and the $\mathrm{REO}_{1.5}$ identity on:

(i) the evolution of the residual melt composition following reactions, including the solubility limits of the TBO constituents in the melt relative to particular reaction product assemblages,

(i) (ii) the propensity to form apatite relative to other crystalline silicates, and

(iii) the nature and crystal chemistry origins of variations in reaction product composition and the implications of cation partitioning between various reaction products on the reaction efficiency.

\section{EXPERIMENTAL APPROACH}

Mixtures of thermal barrier oxides and synthetic silicate deposit powders were equilibrated at $1300^{\circ} \mathrm{C}$ and characterized to determine the equilibrium phase assemblage and solution phase compositions.

\section{$2.1 \quad$ Materials}

Based on knowledge of the relevant phase equilibria, Zaleski et al. developed a set of synthetic deposits that captures a range of melting and crystallization behavior [16]. A subset of these compositions, identified in Table 2 and Figure $1_{2}$ was selected to span a range of $\mathrm{SiO}_{2}: \mathrm{CaO}$ ratios and to probe the role of $\mathrm{MgO}$ on crystallization. For simplicity, other minor constituents expected to have only secondary influence on the reactions (e.g. oxides of Fe, Ti, $\mathrm{Na}, \mathrm{K}$ ) were not included. $\mathrm{C}_{36} \mathrm{~A}_{14} \mathrm{~S}_{50}{ }^{\mathrm{d}}, \mathrm{C}_{24} \mathrm{~A}_{17} \mathrm{~S}_{59}$, and $\mathrm{C}_{15} \mathrm{~A}_{15} \mathrm{~S}_{70}$ have similar $\mathrm{AlO}_{1.5}$ content but vary the $\mathrm{Si}: \mathrm{Ca}$ ratio from 1.4 to 4.7. $\mathrm{C}_{33} \mathrm{M}_{9} \mathrm{~A}_{13} \mathrm{~S}_{45}$, originally chosen based on the composition of the liquid that had infiltrated column gaps in ex-service airfoild [18], provides a useful comparison to many past studies. $\mathrm{C}_{36} \mathrm{~A}_{14} \mathrm{~S}_{50}$ maintains the same $\mathrm{Ca}$ :Al:Si proportions as $\mathrm{C}_{33} \mathrm{M}_{9} \mathrm{~A}_{13} \mathrm{~S}_{45}$ while removing $\mathrm{MgO} . \mathrm{C}_{24} \mathrm{~A}_{17} \mathrm{~S}_{59}$ is the lowest ternary eutectic ${ }^{\mathrm{e}}$ in the CAS ternary [19]. The FactSage free energy

d Abbreviated molar concentrations are used throughout the manuscript: $\mathrm{C}_{36} \mathrm{~A}_{14} \mathrm{~S}_{50}$ corresponds to $36 \mathrm{~mol} \% \mathrm{CaO}$, $14 \mathrm{~mol} \% \mathrm{AlO}_{1.5}$, and $50 \mathrm{~mol} \% \mathrm{SiO}_{2}$.

e This nominal eutectic composition, used by $\mathrm{MaO}$ et al. in their thermodynamic assessment [19], differs slightly from the eutectic calculated by the FTOxid database, $\mathrm{C}_{26} \mathrm{~A}_{15} \mathrm{~S}_{59}$, which is shown in Figure 1(a) and used to calculate the temperatures in Table 2. 
minimization software (with FTOxid database [20]) was used to provide additional insight into the $\mathrm{CaO}-(\mathrm{MgO})-\mathrm{AlO}_{1.5}-\mathrm{SiO}_{2}$ phase equilibria.

The C(M)AS powders were produced by solid state reaction of mixed oxides below the respective incipient melting temperatures $[16,21]$. The measured onsets of melting for the three CAS compositions were in the range $1125^{\circ} \mathrm{C}$ to $1140^{\circ} \mathrm{C}$ while that for $\mathrm{C}_{33} \mathrm{M}_{9} \mathrm{~A}_{13} \mathrm{~S}_{45}$ was $1233^{\circ} \mathrm{C}$ [16].

The equilibria were assessed between the four deposit compositions and $\mathrm{ZrO}_{2}$, $\mathrm{Y}_{0.08} \mathrm{Zr}_{0.92} \mathrm{O}_{1.96}$ (7YSZ), $\mathrm{Y}_{4} \mathrm{Zr}_{3} \mathrm{O}_{12}$ ( $\delta$-phase), $\mathrm{Gd}_{2} \mathrm{Zr}_{2} \mathrm{O}_{7}$ (pyrochlore), $\mathrm{YO}_{1.5}$, or $\mathrm{GdO}_{1.5}$. The $7 \mathrm{YSZ}, \mathrm{Y}_{4} \mathrm{Zr}_{3} \mathrm{O}_{12}$, and $\mathrm{Gd}_{2} \mathrm{Zr}_{2} \mathrm{O}_{7}$ represent current or prospective TBC materials and were synthesized by precipitation of hydroxides from a precursor solution followed by pyrolysis at $1000^{\circ} \mathrm{C}$, as described elsewhere [7]. The pure oxides capture the reactivity of the individual coating components. $\underline{\mathrm{YO}}_{1.5}(2 \mu \mathrm{m}, 99.9 \%)$ and $\mathrm{GdO}_{1.5}(<10 \mu \mathrm{m}, 99.9 \%)$ were procured from Alfa Aesar, Ward Hill, MA and $\mathrm{ZrO}_{2}(-325$ mesh, 99\%) was obtained from Sigma-Aldrich, St. Louis, MO.

\subsection{Equilibration}

The deposit and thermal barrier oxide powders were combined to achieve a $25 \mathrm{~mol} \%$ concentration of the TBO cations, e.g. $0.75 \mathrm{C}_{33} \mathrm{M}_{9} \mathrm{~A}_{13} \mathrm{~S}_{45}+0.25 \mathrm{G}_{50} \mathrm{Z}_{50},\left(\mathrm{Gd}_{2} \mathrm{Zr}_{2} \mathrm{O}_{7}\right)$ has the overall composition $\mathrm{C}_{24.75} \mathrm{M}_{6.75} \mathrm{~A}_{9.75} \mathrm{~S}_{33.75} \mathrm{G}_{12.5} \mathrm{Z}_{12.5}$. This proportion captures the reactions relevant to early-stage CMAS-TBC interaction, where minor differences in the equilibria could have a pronounced influence on the mitigation efficiency. The composition was also selected to retain the liquid phase to measure the $\mathrm{ZrO}_{2}, \mathrm{YO}_{1.5}$, and $\mathrm{GdO}_{1.5}$ saturation limits with respect to various reaction products. Previous experiments showed that mixtures with higher TBO content (e.g.

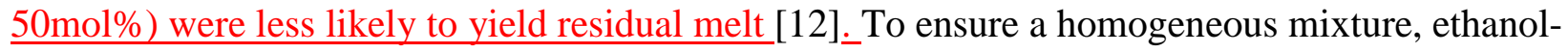
based slurries were ground in an alumina mortar and pestle until dry. The mixed powders were cold pressed into $6 \mathrm{~mm}$ diameter pellets weighing approximately $0.15 \mathrm{~g}(\sim 1.5 \mathrm{~mm}$ thick $)$.

The pellets were wrapped in platinum foil, suspended by platinum wire from an alumina $\underline{\text { rack in a box furnace, annealed for } 50 \mathrm{~h} \text { or } 200 \mathrm{~h} \text { at } 1300^{\circ} \mathrm{C}_{2} \text { and quenched by rapid withdrawl into }}$ air (<30s to reach ambient temperature). This approach allowed for simultaneous equilibration and quenching of multiple molten samples in non-reactive containers. The longer annealing time was used in cases where partially reacted material remained trapped within the reaction products after 50h. 


\subsection{Analysis}

The equilibrated specimens were mounted in epoxy, cross sectioned, and polished to a $0.5 \mu \mathrm{m}$ finish using diamond suspensions. The microstructures were characterized using backscattered electron imaging (BSE-SEM, XL30 Sirion FEG, FEI, Hillsboro, OR) and transmission electron microscopy (TEM, Technai G2 Sphera, FEI). Phase identification relied on measured compositions and phase morphology, based on previous experience with the phases $[12,17]$. In most cases the phases were uniformly distributed in the solidified melt. When heterogeneity (due to differences in buoyancy) was observed, the phase compositions were measured in areas with high and low precipitate volume fractions. The melt compositions in the respective areas were indistinguishable, indicating that the selective settling of denser phases did $\underline{\text { not influence the global equilibrium. }}$

Compositions were measured by electron probe microanalysis (EPMA, SX-100, Cameca, Madison, WI) or, for cases with small grain size, energy dispersive spectroscopy in the TEM (TEM-EDS, Oxford, Concord, MA). The TEM-EDS quantification employed fluorite and amorphous $\mathrm{C}_{33} \mathrm{M}_{9} \mathrm{~A}_{13} \mathrm{~S}_{45}$ standards characterized by ICP-MS. Based on comparison with internal standards, errors are of order $1 \%$ and $5 \%$ of the measured values for EPMA and TEM-EDS,

respectively. For convenience in distinguishing data from the two sources, the EPMA and TEMEDS results are reported to $0.1 \mathrm{~mol} \%$ and $1 \mathrm{~mol} \%$ precision, respectively.

\section{RESULTS}

\subsection{Phase Equilibria in Silicate Deposits}

In service only a portion of the ingested debris is likely to melt and infiltrate the TBC. The remainder of the adhered material accumulates as a semi-solid deposit on the coating surface (with its own implications for thermo-cyclic durability). The anticipated melting and intrinsic crystallization behavior for $\mathrm{CaO}-\mathrm{AlO}_{1.5}-\mathrm{SiO}_{2}$ deposits, based on FactSage calculations, is show $\underline{\underline{n}}$ in Figure 1(a). The influence of moderate $\mathrm{MgO}$ addition $\left(9 \mathrm{~mol} \% \mathrm{MgO}\right.$ for $\left.\mathrm{C}_{33} \mathrm{M}_{9} \mathrm{~A}_{13} \mathrm{~S}_{45}\right)$ is illustrated in Figure 1(b). In both diagrams the range of compositions expected to be completely molten at $1300^{\circ} \mathrm{C}$ is superimposed on the liquidus projection with darker shading. The deposit compositions that may melt partially (forming liquid compositions around the perimeter of the

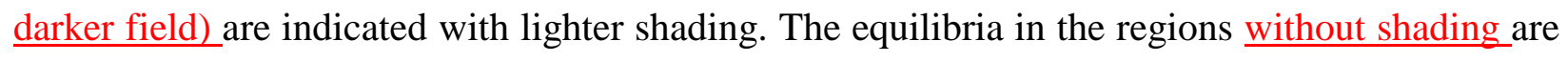
below the solidus at $1300^{\circ} \mathrm{C}$. 
Melting in the CAS system, Figure 1(a), occurs via the eutectic reaction between tridymite $\left(\mathrm{S}_{2}\right.$, anorthite $\left(\mathrm{CA}_{2} \mathrm{~S}_{2}\right)+$ pseudo-wollastonite $(\mathrm{CS})$ at $\sim 1185^{\circ} \mathrm{C}$ or the $\sim 1257^{\circ} \mathrm{C}$ eutectic involving $\mathrm{CA}_{2} \mathrm{~S}_{2}+\mathrm{CS}+\mathrm{C}_{2} \mathrm{~A}_{2} \mathrm{~S}$ (gehlenite, a melilite end member). At $1300^{\circ} \mathrm{C}$ the liquid field spans a $\sim 25 \mathrm{~mol} \%$ change in both $\mathrm{SiO}_{2}$ and $\mathrm{CaO}$ concentration but less than a $10 \mathrm{~mol} \%$ change in the $\mathrm{AlO}_{1.5}$ content. $\mathrm{MgO}$ addition, Figure 1(b), shifts the melilite field and stabilizes diopside $\left(\mathrm{MCS}_{2}\right)$, altering the solidus temperatures and increasing the range of $\mathrm{AlO}_{1.5}$ concentrations in the liquid field. However, as illustrated by the overlaid fields in Figure 1(c), the MgO-containing liquid does not extend as far toward the $\mathrm{CaO}$ corner.

Based on the calculated equilibria the $\mathrm{C}_{33} \mathrm{M}_{9} \mathrm{~A}_{13} \mathrm{~S}_{45}$ and $\mathrm{C}_{24} \mathrm{~A}_{17} \mathrm{~S}_{59}$ deposit compositions are in the liquid fields at $1300^{\circ} \mathrm{C} . \mathrm{C}_{36} \mathrm{~A}_{14} \mathrm{~S}_{50}$ is in the CS crystallization field on the $\mathrm{AlO}_{1.5}$-lean side of the liquid field, and $\mathrm{C}_{15} \mathrm{~A}_{15} \mathrm{~S}_{70}$ falls beyond the $\mathrm{SiO}_{2}$-saturated end of the liquid field. The observed phases for the pure deposits equilibrated at $1300^{\circ} \mathrm{C}$, Figure 2 and Table 3, agree with the calculated equilibria. The single-phase melts produced by $\mathrm{C}_{33} \mathrm{M}_{9} \mathrm{~A}_{13} \mathrm{~S}_{45}$ and $\mathrm{C}_{24} \mathrm{~A}_{17} \mathrm{~S}_{59}$, Figure 2(a,c), were quenched as glasses. $\mathrm{C}_{36} \mathrm{~A}_{14} \mathrm{~S}_{50}$ yielded liquid and $\mathrm{CaSiO}_{3}$, Figure 2(b), and $\mathrm{C}_{15} \mathrm{~A}_{15} \mathrm{~S}_{70}$ produced a mixture of liquid and crystalline ${ }^{\mathrm{f}} \mathrm{SiO}_{2}$, Figure 2(d). The partitioning between the melt and crystalline phases for $\mathrm{C}_{36} \mathrm{~A}_{14} \mathrm{~S}_{50}$ and $\mathrm{C}_{15} \mathrm{~A}_{15} \mathrm{~S}_{70}$, Table 4 , is consistent with the melt compositions calculated using the FactSage FTOxid database, Table 2.

\subsection{Equilibria with $\mathrm{ZrO}_{2}$ and $7 \mathrm{YSZ}$}

Figure 3 shows the microstructures for $\mathrm{ZrO}_{2}$ and $7 \mathrm{YSZ}$ reacted with the model deposits. The equilibrium phases for each combination are summarized in Table 3. No new phases are formed by interaction with $\mathrm{C}_{33} \mathrm{M}_{9} \mathrm{~A}_{13} \mathrm{~S}_{45}$ and $\mathrm{C}_{36} \mathrm{~A}_{14} \mathrm{~S}_{50}$, although the $\mathrm{CaSiO}_{3}$ present in the pure $\mathrm{C}_{36} \mathrm{~A}_{14} \mathrm{~S}_{50}$ is now absent. The $\mathrm{ZrO}_{2}$ grains in Figure 3(a-c) contain up to $0.6 \mathrm{~mol} \% \mathrm{CaO}$ suggesting that the $\mathrm{ZrO}_{2}$ dissolves and reprecipitates with a modified composition. Likewise, the dissolution/reprecipitation of $7 \mathrm{YSZ}$ in $\mathrm{C}_{33} \mathrm{M}_{9} \mathrm{~A}_{13} \mathrm{~S}_{45}$ and $\mathrm{C}_{36} \mathrm{~A}_{14} \mathrm{~S}_{50}$, e.g. Figure 4(a), yields heavily twinned $\mathrm{ZrO}_{2}$ grains (indicative of the tetragonal to monoclinic transformation on cooling) containing approximately $3 \mathrm{~mol} \% \mathrm{YO}_{1.5}$ and $1 \mathrm{~mol} \% \mathrm{CaO}$. Therefore, the $\mathrm{ZrO}_{2}$ phase present in equilibrium at high temperature is identified as tetragonal. The residual melts contained less than $3 \mathrm{~mol} \%$ each of dissolved $\mathrm{ZrO}_{2}$ and $\mathrm{YO}_{1.5}$, Table 4. Compared to the $\mathrm{Y}: \mathrm{Zr}$ ratio in the $\mathrm{YSZ}$, the relative $\mathrm{YO}_{1.5}$ enrichment in the melt is consistent with the $\mathrm{YO}_{1.5}$ depletion

f The equiaxed, moderately faceted appearance of the $\mathrm{SiO}_{2}$ grains suggest that it precipitated as $\beta$-cristobalite, rather than the expected tridymite form, while the extensive cracking is indicative of the $\beta \rightarrow \alpha$ transition below the glass transition temperature of the residual melt. 
in the reprecipitated $\mathrm{ZrO}_{2}$. There was not an apparent correlation between the $\mathrm{C}(\mathrm{M}) \mathrm{AS}$ composition and the $\underline{\mathrm{ZrO}}_{2}$ and $\mathrm{YO}_{1.5}$ solubility limits.

Zircon $\left(\mathrm{ZrSiO}_{4}\right)$ crystallizes upon reaction between $\mathrm{ZrO}_{2}$ or $7 \mathrm{YSZ}$ and the higher $\mathrm{SiO}_{2}$ deposits, $\mathrm{C}_{24} \mathrm{~A}_{17} \mathrm{~S}_{59}$ and $\mathrm{C}_{15} \mathrm{~A}_{15} \mathrm{~S}_{70}$. The reactions with $\mathrm{C}_{24} \mathrm{~A}_{17} \mathrm{~S}_{59}$ yield zircon and reprecipitated $\mathrm{ZrO}_{2}$, Figures $3(\mathrm{c}, \mathrm{g})$, suggesting that the $\mathrm{SiO}_{2}$ content to move the system from a phase field containing zircon and $\mathrm{t}-\mathrm{ZrO}_{2}$ to one containing only zircon. The further increase in $\mathrm{SiO}_{2}$ content from $\mathrm{C}_{24} \mathrm{~A}_{17} \mathrm{~S}_{59}$ to $\mathrm{C}_{15} \mathrm{~A}_{15} \mathrm{~S}_{70}$ promotes additional zircon crystallization. Following equilibration of $\mathrm{C}_{15} \mathrm{~A}_{15} \mathrm{~S}_{70}$ with $\mathrm{ZrO}_{2}$ or $\mathrm{YSZ}$, zircon is the only $\mathrm{ZrO}_{2}$-bearing phase in contact with the melt, Figures $3(\mathrm{~d}, \mathrm{~h})$. Small particles of unreacted $\mathrm{ZrO}_{2} / 7 \mathrm{YSZ}$ remain embedded inside the larger zircon grains in these specimens, even after annealing for $200 \mathrm{~h}$. The morphology suggests that, once formed, the zircon shell hinders the transport required for further reaction. The zircon in the YSZ specimens contained $2 \mathrm{~mol} \% \mathrm{YO}_{1.5}$ with a corresponding reduction in the $\mathrm{ZrO}_{2}$ content, Table 5.

The reactions between $\mathrm{ZrO}_{2}$ and $\mathrm{C}_{24} \mathrm{~A}_{17} \mathrm{~S}_{59}$ or $\mathrm{C}_{15} \mathrm{~A}_{15} \mathrm{~S}_{70}$ also promote the crystallization of anorthite $\left(\mathrm{CaAl}_{2} \mathrm{Si}_{2} \mathrm{O}_{8}\right)$, Figure 3(c); this phase was not observed in the equivalent $7 \mathrm{YSZ}$ specimens, Figure 3(g).

\subsection{Equilibria with $\mathrm{Y}_{4} \mathrm{Zr}_{3} \mathrm{O}_{12}$ and $\mathrm{Gd}_{2} \mathrm{Zr}_{2} \mathrm{O}_{7}$}

Apatite and one or more $\mathrm{ZrO}_{2}$-rich phases are formed by the reactions between each deposit and $\mathrm{Y}_{4} \mathrm{Zr}_{3} \mathrm{O}_{12}$ or $\mathrm{Gd}_{2} \mathrm{Zr}_{2} \mathrm{O}_{7}$, Figure 5(a-h). The concentrations of $\mathrm{CaO}$ and $\mathrm{ZrO}_{2}$ in the apatite, Table 6 and Figure $6(\mathrm{a}, \mathrm{b})$, increase with the total $\mathrm{CaO}$ content in the initial deposit. The apatite oxygen stoichiometry, an indicator of the nature of defects contributing to the solution behavior, was calculated based on general formula ( $\mathrm{RE}, \mathrm{Ca}, \mathrm{Zr})_{10}{\underline{\left(\mathrm{SiO}_{4}\right.}}_{2} \underline{6} \underline{\underline{\mathrm{O}}}$. The results, Figure 6 (c), are effectively constant with $\sim 26$ oxygen atoms per formula unit.

The identity of the $\mathrm{ZrO}_{2}$-rich phases varies with both the deposit composition and $\mathrm{REO}_{1.5}$ identity. Reactions between $\mathrm{Y}_{4} \mathrm{Zr}_{3} \mathrm{O}_{12}$ and $\mathrm{C}_{33} \mathrm{M}_{9} \mathrm{~A}_{13} \mathrm{~S}_{45}, \mathrm{C}_{36} \mathrm{~A}_{14} \mathrm{~S}_{50}$, or $\mathrm{C}_{24} \mathrm{~A}_{17} \mathrm{~S}_{59}$ yield fluorite containing from $18 \mathrm{~mol} \%$ to $24 \mathrm{~mol} \% \mathrm{YO}_{1.5}$ and $2 \mathrm{~mol} \% \mathrm{CaO}$, Figure 7. The $\mathrm{YO}_{1.5}$ concentration in the fluorite decreases with increasing $\mathrm{SiO}_{2}$ content in the deposit. $\mathrm{Y}_{4} \mathrm{Zr}_{3} \mathrm{O}_{12}$ reacts with $\mathrm{C}_{15} \mathrm{~A}_{15} \mathrm{~S}_{70}$ to yield a combination of apatite and zircon, the latter containing $\sim 2 \mathrm{~mol} \%$ $\mathrm{YO}_{1.5}$. The $\mathrm{Gd}_{2} \mathrm{Zr}_{2} \mathrm{O}_{7}$ reaction with $\mathrm{C}_{33} \mathrm{M}_{9} \mathrm{~A}_{13} \mathrm{~S}_{45}$ yields fluorite, with proportionally more $\mathrm{CaO}$ and less $\mathrm{GdO}_{1.5}$ than the equivalent $\mathrm{Y}_{4} \mathrm{Zr}_{3} \mathrm{O}_{12}$ specimen. The interaction between $\mathrm{Gd}_{2} \mathrm{Zr}_{2} \mathrm{O}_{7}$ and $\mathrm{C}_{36} \mathrm{~A}_{14} \mathrm{~S}_{50}$ produces apatite and transformable tetragonal $\mathrm{ZrO}_{2}$ (Figure 4(b)) with $<5$ mol\% 
$\mathrm{GdO}_{1.5}$. The $\mathrm{C}_{24} \mathrm{~A}_{17} \mathrm{~S}_{59}+\mathrm{Gd}_{2} \mathrm{Zr}_{2} \mathrm{O}_{7}$ equilibria includes apatite, $\mathrm{t}-\mathrm{ZrO}_{2}$, and zircon while the reaction with $\mathrm{C}_{15} \mathrm{~A}_{15} \mathrm{~S}_{70}$ forms apatite and zircon.

The $\mathrm{ZrO}_{2}$ concentrations in the residual melts, Table 4, were comparable to those measured for reactions with $\mathrm{ZrO}_{2}$ or $7 \mathrm{YSZ}$. The $\mathrm{REO}_{1.5}$ concentration decreases with increasing $\mathrm{CaO}$ concentration in the initial deposit, Figure 8; the $\mathrm{YO}_{1.5}$ concentrations were slightly higher than the $\mathrm{GdO}_{1.5}$ concentrations for each deposit.

\section{$3.4 \quad$ Equilibria with $\mathrm{YO}_{1.5}$ and $\mathrm{GdO}_{1.5}$}

The diversity of the reaction products and the extent of melt crystallization were greatest for the pure $\mathrm{REO}_{1.5}$. As with the zirconates, apatite was formed with every deposit composition, Figure 9(a-h). However, unlike the $\mathrm{ZrO}_{2}$-containing systems, the apatite composition (i.e. Ca:RE ratio) was essentially equivalent for all deposits, Table 6 and Figure 6(a).

No residual glass was observed in the equilibrated $\mathrm{C}_{33} \mathrm{M}_{9} \mathrm{~A}_{13} \mathrm{~S}_{45}+\mathrm{YO}_{1.5}$ specimen. The microstructure contained apatite and large grains of garnet, $\left(\mathrm{Y}_{0.63} \mathrm{C}_{0.33} \mathrm{M}_{0.04}\right)_{3}\left(\mathrm{M}_{0.6} \mathrm{~A}_{0.4}\right)_{2}\left(\mathrm{~S}_{0.77} \mathrm{~A}_{0.23}\right)_{3} \mathrm{O}_{12}$, and melilite, $\mathrm{Ca}_{2}\left(\mathrm{~A}_{0.51} \mathrm{M}_{0.63}\right)\left(\mathrm{A}_{0.57} \mathrm{~S}_{0.73}\right) \mathrm{SiO}_{7}$, solid solutions. TEM characterization, Figure 10(a), reveals that garnet is also present between the apatite grains, consistent with previously reported observations of slower growing garnet engulfing the faster growing reaction products [7, 11]. The related $\mathrm{C}_{33} \mathrm{M}_{9} \mathrm{~A}_{13} \mathrm{~S}_{45}+\mathrm{GdO}_{1.5}$ specimen also contained a large volume of apatite and melilite but not a $\mathrm{GdO}_{1.5}$-bearing garnet. Instead, magnesium aluminate spinel was evident, Figure 9(e). The regions between these crystalline phases were filled with glass, Figure 10(b). The small apatite grains embedded in the melilite and spinel suggests that apatite precipitation precedes the other phases.

Melilite, spinel, and garnet were not observed in the CAS specimens. Reactions between $\mathrm{C}_{36} \mathrm{~A}_{14} \mathrm{~S}_{50}$ and $\mathrm{YO}_{1.5}$ produced a combination of apatite, anorthite, and silicocarnotite $\left(\mathrm{Ca}_{3} \mathrm{Y}_{2} \mathrm{Si}_{3} \mathrm{O}_{12}\right)$. The latter phase is known to exist in equilibrium with the liquid phase in the tCaO- $\mathrm{SiO}_{2}-\mathrm{YO}_{1.5}$ system [17]. Apatite was the only crystalline phase in the equivalent $\mathrm{GdO}_{1.5}$ specimen. $\mathrm{C}_{24} \mathrm{~A}_{17} \mathrm{~S}_{59}$ reacts with both $\mathrm{YO}_{1.5}$ and $\mathrm{GdO}_{1.5}$ to produce apatite and anorthite, Figure 9(c,g) and Figure 10(c). The reaction between $\mathrm{YO}_{1.5}$ and $\mathrm{C}_{15} \mathrm{~A}_{15} \mathrm{~S}_{70}$ produced a mixture of apatite and yttrium disilicate $\left(\mathrm{Y}_{2} \mathrm{Si}_{2} \mathrm{O}_{7}\right)$. The equivalent $\mathrm{GdO}_{1.5}$ specimen, Figure 10(d), contained apatite, anorthite, and crystalline $\mathrm{SiO}_{2}$, but not gadolinium disilicate. 


\section{DISCUSSION}

The reactivity between thermal barrier oxides and silicate deposits is strongly dependent on the initial composition of the latter. Variations are also observed between different $\mathrm{REO}_{1.5}$ (i.e $\mathrm{Y}$ vs. $\mathrm{Gd}$ ) and with changes in the $\mathrm{REO}_{1.5}$ content of the $\mathrm{TBO}$ (i.e. $\mathrm{ZrO}_{2} \rightarrow 7 \mathrm{YSZ} \rightarrow$ $\mathrm{Y}_{4} \mathrm{Zr}_{3} \mathrm{O}_{12} \rightarrow \mathrm{YO}_{1.5}$ ). The results are discussed in terms of (i) shifts in the residual melt composition following the reactions, (ii) the predominance of various crystalline silicate reaction products and (iii) their solid solution behavior, and (iv) implications for the development of degradation tests and models to aid the design of TBCs that are resistant to degradation by a range of silicate deposit compositions.

\subsection{Residual Melt Composition}

\subsubsection{Evolving Melt Composition}

The composition of the melt evolves as crystallization proceeds. These changes affect the nature of secondary intrinsic crystallization, discussed in Section 4.2, and the viscosity ( $\eta$ ) of the melt. The time to infiltrate a given TBC thickness decreases with the viscosity [13], which itself scales with the degree of connectivity in the $\mathrm{SiO}_{2}$ network. In this context, reactions that selectively deplete $\mathrm{SiO}_{2}$ would decrease $\eta$, accelerating infiltration ${ }_{2}$ while reactions selectively depleting modifiers (e.g. $\mathrm{CaO}, \mathrm{MgO}$ ) would increase $\eta$ and retard melt infiltration. The

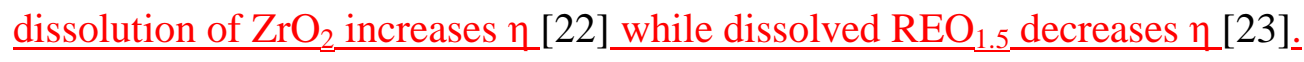

The changes in the $\mathrm{SiO}_{2}$ content between the initial and residual melt are most pronounced, Figure 11 (a). Except for cases where no new phases were formed $\left(\mathrm{ZrO}_{2}\right.$ and $7 \mathrm{YSZ}$ interaction with $\mathrm{C}_{33} \mathrm{M}_{9} \mathrm{~A}_{13} \mathrm{~S}_{45}$ or $\mathrm{C}_{36} \mathrm{~A}_{14} \mathrm{~S}_{50}$ ), the $\mathrm{SiO}_{2}$ concentration in the melt always decreases. The magnitude of the change depends on the specific reactions. No single TBO among those examined offers a clear advantage for all deposits. For instance, the reactions of $\mathrm{C}_{36} \mathrm{~A}_{14} \mathrm{~S}_{50}$ with

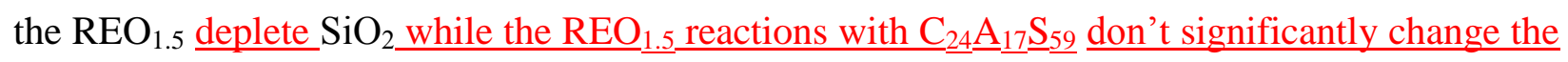
$\underline{\mathrm{SiO}}_{2}$ content. This trend is reversed when the same deposits react with $\mathrm{ZrO}_{2}$ and $7 \mathrm{YSZ}$.

Apatite precipitation consumes $\mathrm{CaO}$ and $\mathrm{SiO}_{2}$ from the melt and could, in principle, deplete the melt in $\mathrm{CaO}$. However, the $\mathrm{Si}: \mathrm{Ca}$ ratios in the residual melt decrease, Figure 11(b), indicating $\mathrm{CaO}$ enrichment. The initial Si:Ca ratios in $\mathrm{C}_{33} \mathrm{M}_{9} \mathrm{~A}_{13} \mathrm{~S}_{45}$ and $\mathrm{C}_{36} \mathrm{~A}_{14} \mathrm{~S}_{50}$ (both 1.4) are less than the corresponding apatite $(\mathrm{Si}: \mathrm{Ca} \approx 3)$, leading to progressive $\mathrm{CaO}$ enrichment during apatite crystallization. Conversely, the initially $\mathrm{CaO}$-lean deposits form multiple silicates (e.g., 
apatite and zircon) that, when combined, also decrease the Si:Ca ratio. The only exception is $\mathrm{GdO}_{1.5}+\mathrm{C}_{33} \mathrm{M}_{9} \mathrm{~A}_{13} \mathrm{~S}_{45}$ wherein the crystallization of $\mathrm{CaO}$-rich melilite depletes $\mathrm{CaO}$.

Previously described infiltration models $[4,13]$ indicate that the infiltration time scales linearly with the viscosity. The large changes in melt viscosity are therefore expected to significantly influence the local rate of infiltration in a TBC. Silicate liquid viscosity models [22, 24] enable comparison between the properties of various melts. Unfortunately these models are

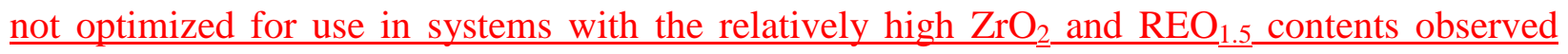
here. As an approximation, the residual melt viscosities were instead calculated based on the

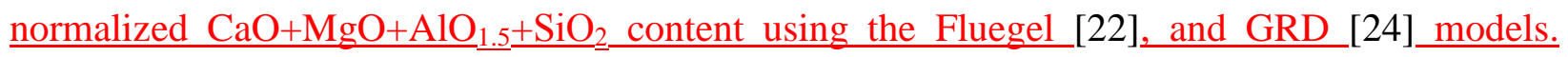
Although there were differences in the values obtained from the two models, both showed similar trends. The results obtained from the GRD model are plotted in Figure 11(c). Based on the changes in CMAS content, the viscosity is observed to drop between one and three orders of magnitude cases involving silicate precipitation. The key conclusion is that although crystallization reactions are deemed desirable for their ability to consume the melt and block infiltration channels, the beneficial effect may be partially counteracted if the viscosity of the infiltrating melt progressively decreases.

\subsubsection{REO ${ }_{1.5}$ Solubility in the Melt}

The $\mathrm{REO}_{1.5}$ melt saturation limit in equilibrium with apatite decreases with the $\mathrm{CaO}$ concentration in the deposit, Figure 8. The $\mathrm{GdO}_{1.5}$ concentrations were consistently lower than $\mathrm{YO}_{1.5}$. The influence of $\mathrm{ZrO}_{2}$ (c.f. results for the $\underline{\mathrm{RE}}$-zirconates and pure $\underline{\mathrm{REO}}_{1.5}$ ) was negligible. This solubility is determined in part by the influence of the local melt structure on the RE coordination $[25,26]$. The increased fraction of non-bridging oxygen (NBO) atoms in the deposits with a high modifier content (e.g. $\mathrm{C}_{33} \mathrm{M}_{9} \mathrm{~A}_{13} \mathrm{~S}_{45}, \mathrm{C}_{36} \mathrm{~A}_{14} \mathrm{~S}_{50}$ ) facilitates a more regular $\mathrm{RE}^{3+}$ coordination shell and increased $\mathrm{REO}_{1.5}$ solubility. Additionally, the smaller $\mathrm{Y}^{3+}$ should be six-coordinated in the melt while the larger $\mathrm{Gd}^{3+}$ would prefer to have a higher coordination state, implying reduced solubility for a given NBO content.

In service, the effect of variations in $\underline{\mathrm{REO}}_{1.5}$ solubility will be most pronounced in the early stages of interaction between a TBC and a silicate melt. Specifically, the solubility limit determines the fraction of the TBC that must dissolve to saturate the melt and initiate reactive crystallization. Assuming comparable dissolution rates, higher solubility implies a longer interaction time without crystallization allowing more time for the melt to infiltrate. For instance, $\underline{\text { to }}$ initiate apatite crystallization roughly twice the volume of $\mathrm{Y}_{4} \mathrm{Zr}_{3} \mathrm{O}_{12}$ must dissolve into 
$\mathrm{C}_{33} \mathrm{M}_{9} \mathrm{~A}_{13} \mathrm{~S}_{45}$ compared to $\mathrm{C}_{15} \mathrm{~A}_{15} \mathrm{~S}_{70}$. Similarly, the $\sim 50 \%$ increase in $\mathrm{YO}_{1.5}$ solubility compared to $\mathrm{GdO}_{1.5}$ implies that a $\mathrm{GdO}_{1.5}$-containing coating should form apatite more quickly. Unfortunately, the solubility is highest in the deposits that, due to their lower viscosity, would infiltrate most rapidly.

\section{2_Reaction Product Predominance}

It is desirable for reactions between the melt and TBO to produce phases with fast crystallization kinetics and with morphologies that would effectively seal infiltration pathways. In this context systems that produce apatite with concomitant intrinsic crystallization are preferable to those yielding other crystallization products. The following sections discuss the results in terms of the relative tendency to form various $\mathrm{REO}_{1.5}$-based silicates, the factors contributing to intrinsic crystallization and zircon formation, and the influence of $\mathrm{MgO}$ on these crystallization reactions.

\subsection{Formation of REO 1.5 -rich Silicates}

Apatite is observed for all deposits upon reaction with the $\underline{\mathrm{Y}}_{4} \underline{\mathrm{Zr}}_{3} \underline{\mathrm{O}}_{12}, \mathrm{Gd}_{2} \underline{\mathrm{Zr}}_{2} \underline{\mathrm{O}}_{7}$, and $\mathrm{REO}_{1.5}$. This indicates that apatite is stable in contact with melts covering a wide range of $\mathrm{Si}: \mathrm{Ca}$ ratios. Secondary effects related to the apatite composition and presence of other reaction products, elaborated below, influence the amount of apatite crystallized for a given fraction of $\mathrm{REO}_{1.5}$ in the system.

For $\mathrm{Y}_{4} \mathrm{Zr}_{3} \mathrm{O}_{12}$ and $\mathrm{Gd}_{2} \mathrm{Zr}_{2} \mathrm{O}_{7}$, apatite is the only $\underline{\mathrm{RE}}$-bearing silicate formed. The presence of $\mathrm{REO}_{1.5}$ in the reprecipitated $\mathrm{ZrO}_{2}$ and the melt reduce the amount of apatite formed relative to a scenario where all of the $\mathrm{REO}_{1.5}$ precipitates as apatite. Systems with low $\mathrm{REO}_{1.5}$ solubility in the melt and those forming zircon or $\mathrm{REO}_{1.5}$-lean tetragonal $\mathrm{ZrO}_{2}$ instead of the $\mathrm{REO}_{1.5}$-rich fluorite may increase the volume of apatite formed..

The pure $\mathrm{REO}_{1.5}$ systems should produce more apatite crystallization than the zirconates (for a fixed total $\mathrm{REO}_{1.5}$ content) by eliminating the undesired precipitation of $\mathrm{REO}_{1.5}$ in the fluorite phase. However, the appearance of alternate $\mathrm{YO}_{1.5}$-bearing silicates (garnet, silicocarnotite, and disilicate) limits apatite formation. Based on their morphology, these phases may nucleate and/or grow more slowly than apatite, reducing their relative effectiveness for arresting melt infiltration in a TBC. The absence of these phases in the $\mathrm{GdO}_{1.5}$ systems points to a desirable increase in the stability of $\mathrm{GdO}_{1.5^{-}}$-apatite relative to $\mathrm{GdO}_{1.5^{-}}$garnet, -silicocarnotite, 
and -disilicate. Except for the modest $\mathrm{GdO}_{1.5}$ solubility in the residual melt, all of the $\mathrm{GdO}_{1.5}$ in each system is converted to apatite.

\subsection{Intrinsic crystallization}

There are two notable observations regarding the intrinsic crystallization behavior for the deposits of interest. First, the dissolution of $\mathrm{ZrO}_{2}$ and/or $\mathrm{YO}_{1.5}$ into the melt can suppress intrinsic crystallization. In other words, TBC dissolution initially expands the liquid field (dark fields in Figure 1). The implication is that compared to the intrinsic crystallization $\underline{\text { temperature/rate for the initial deposit alone, coating dissolution can retard crystallization as the }}$ melt penetrates against a thermal gradient. This effect is most apparent in the $\mathrm{ZrO}_{2}$ and $7 \mathrm{YSZ}$ systems. The $\mathrm{CaSiO}_{3}$ present in the initial $\mathrm{C}_{36} \mathrm{~A}_{14} \mathrm{~S}_{50}$ deposit disappears in the mixed systems even through the bulk deposit composition remains unchanged. Additionally, the appearance of anorthite in $\mathrm{C}_{24} \mathrm{~A}_{17} \mathrm{~S}_{59} / \mathrm{C}_{15} \mathrm{~A}_{15} \mathrm{~S}_{70}+\mathrm{ZrO}_{2}$ but not \pm 7YSZ suggests that $\mathrm{ZrO}_{2}$ and $\mathrm{YO}_{1.5}$ together increase the liquid stability more than $\mathrm{ZrO}_{2}$ alone.

The changes in the melt composition upon reactive crystallization (e.g., $\mathrm{SiO}_{2}$ depletion as apatite and zircon precipitate) may promote intrinsic crystallization. With a sufficient proportional reduction in $\mathrm{SiO}_{2}$ (or coupled $\mathrm{CaO}+\mathrm{SiO}_{2}$ depletion), the three CAS deposits can shift into the anorthite field while $\mathrm{C}_{33} \mathrm{M}_{9} \mathrm{~A}_{13} \mathrm{~S}_{45}$ could shift melilite, anorthite, and/or spinel fields (see Figure 1). All three phases were observed in multiple equilibrated mixtures while the fraction of the phases formed was determined by the local equilibria. Due to the influence of intrinsic crystallization on $\mathrm{V}_{\text {crys }} / \underline{V}_{\mathrm{TBO}}$, it is important that efforts to model the melt and reaction behavior consider the likelihood of forming secondary reaction products (i.e. the total phase equilibria).

\subsection{Zircon Crystallization}

Based on mass balance alone, zircon could be a desirable reaction product. It dissolves $\underline{\text { less } \mathrm{REO}_{1.5}} \underline{\text { than fluorite or } \mathrm{t}-\mathrm{ZrO}_{2}} \underline{2}_{2}$ making more $\mathrm{REO}_{1.5}$ available to form apatite, and has a high $\mathrm{V}_{\text {crys }} / \mathrm{V}_{\mathrm{TBO}}$. However, zircon nucleation is reportedly slow (taking as long as 30 minutes [27], compared to seconds for apatite [2]) and growth of zircon encasing the partially reacted TBO (also observed in EB-PVD TBCs [4, 14])_would hinder further coating-melt interaction. For instance, the formation of zircon over columnar $\mathrm{Gd}_{2} \mathrm{Zr}_{2} \mathrm{O}_{7}$ crystals upon interaction with a $\mathrm{SiO}_{2}-$

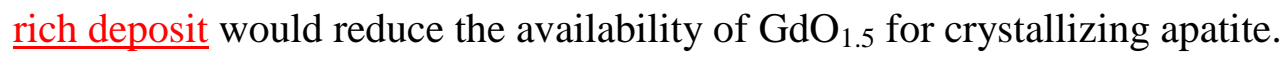




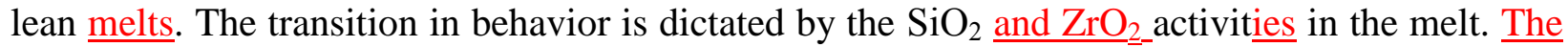
crystalline $\mathrm{SiO}_{2}$ in $\mathrm{C}_{15} \mathrm{~A}_{15} \mathrm{~S}_{70}$ indicates that the $\mathrm{SiO}_{2}$ activity is near unity. Therefore it is unsurprising that zircon crystallization is observed for all $\mathrm{ZrO}_{2}$-containing TBOs. $\underline{\mathrm{C}}_{24} \underline{\mathrm{A}}_{17} \underline{\mathrm{S}}_{59} \underline{\text { is }}$

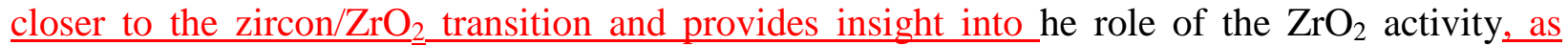
influenced by the presence of the $\mathrm{REO}_{1.5}$.. The reactions with pure $\mathrm{ZrO}_{2}$ should have the highest driving force for zircon crystallization. For the $\mathrm{C}_{24} \mathrm{~A}_{17} \mathrm{~S}_{59}+\mathrm{ZrO}_{2}$ specimen, the zircon-forming reactions reduce the $\mathrm{SiO}_{2}$ content in the melt from 59 mol\% to $52 \mathrm{~mol} \%$. The $2-3 \mathrm{~mol} \% \underline{\mathrm{REO}}_{1.5}$ in the $\mathrm{t}-\mathrm{ZrO}_{2}$ formed from $7 \mathrm{YSZ}$ and $\mathrm{Gd}_{2} \mathrm{Zr}_{2} \mathrm{O}_{7}$ reduces the $\mathrm{ZrO}_{2}$ activity and driving force for zircon crystallization, leading to higher $\mathrm{SiO}_{2}$ concentrations in the residual melt, Table 4 and Figure 11. The absence of zircon in the $\mathrm{Y}_{4} \mathrm{Zr}_{3} \mathrm{O}_{12}+\mathrm{C}_{24} \mathrm{~A}_{17} \mathrm{~S}_{59}$ specimen indicates that the $\mathrm{ZrO}_{2}$ activity is significantly reduced by the $20 \mathrm{~mol} \%$ solute concentration in the fluorite. The implication is that TBCs containing higher initial $\mathrm{REO}_{1.5}$ content (i.e. lower $\mathrm{ZrO}_{2}$ activity) are less likely to form zircon upon reaction with a silicate deposit.

\subsection{Influence of $\mathrm{MgO}$ on Crystallization}

$\mathrm{MgO}$ plays two roles in the phase equilibria. First, $\mathrm{MgO}$ increases the variety of reaction products relative to the CAS deposits. It also influences the partitioning of $\mathrm{REO}_{1.5}$ between apatite and the reprecipitated $\mathrm{ZrO}_{2}$ phase. The reactions between the pure $\mathrm{REO}_{1.5}$ systems and $\mathrm{C}_{33} \mathrm{M}_{9} \mathrm{~A}_{13} \mathrm{~S}_{45}$ produce garnet, melilite, and/or spinel. Each phase contains a significant concentration of $\mathrm{MgO}$ and they were not observed in the CAS systems even though the garnet and melilite phase fields exhibit $\mathrm{MgO}$-free end members. Additionally, $\mathrm{Gd}_{2} \mathrm{Zr}_{2} \mathrm{O}_{7}$ reacts with $\mathrm{C}_{33} \mathrm{M}_{9} \mathrm{~A}_{13} \mathrm{~S}_{45}$ to form fluorite with $\sim 15 \mathrm{~mol} \% \mathrm{GdO}_{1.5}$, whereas the reaction with $\mathrm{C}_{36} \mathrm{~A}_{14} \mathrm{~S}_{50}$ forms $\mathrm{t}-\mathrm{ZrO}_{2}$ with only $\sim 5 \mathrm{~mol} \% \mathrm{GdO}_{1.5}$. Given that neither apatite nor fluorite contains appreciable $\mathrm{MgO}$, this behavior presumably stems from changes in the melt chemistry (i.e. constituent activities) upon $\mathrm{MgO}$ dissolution. For instance, if $\mathrm{MgO}$ reduces the $\mathrm{SiO}_{2}$ activity the driving force for apatite precipitation would decrease leading to an increase in the equilibrium $\mathrm{REO}_{1.5}$ concentration in the melt and reprecipitated fluorite. These influences are important to in-service TBC performance. Given that real-world deposits contain $\mathrm{MgO}$, the present results suggest that model deposit compositions should include at least small fractions of $\mathrm{MgO}$ (as well as $\mathrm{FeO}_{\underline{x}}$ etc) to accurately capture the relevant melt behaviors. 


\subsubsection{Solid Solution Composition Trends}

Several of the reaction products exhibit solid solution behavior allowing their compositions to vary depending on the local chemical conditions. The $\mathrm{V}_{\text {crys }} / \mathrm{V}_{\text {TBO }}$ for a given reaction sequence is impacted by these composition variations. The following sections discuss the composition trends in (i) apatite, (ii) reprecipitated $\mathrm{ZrO}_{2}$, and (iii) zircon. In addition to the implications for TBC reactions with molten silicates, the results provide new insight into the solution behavior of these phases.

\subsubsection{1_Apatite}

The apatite crystal structure and crystal chemistry have been discussed at length in the context of interactions between TBC and molten silicates [6-8, 17, 28]. The structure (with general formula $\left.\mathrm{M}_{4}^{\mathrm{I}} \mathrm{M}_{6}{ }_{6}{ }^{\mathrm{I}}\left(\mathrm{SiO}_{4}\right)_{6} \mathrm{X}_{2}\right)$ contains seven-fold and nine-fold coordinated cation sites, $\mathrm{M}^{\mathrm{I}}$ and $\mathrm{M}^{\mathrm{II}}$, respectively, and anion sites, $\mathrm{X}$, distinct from the oxygen in the silica tetrahedra. $\mathrm{Ca}$ is believed to reside only on the $\mathrm{M}^{\mathrm{I}}$ sites, RE may sit on either the $\mathrm{M}^{\mathrm{I}}$ or $\mathrm{M}^{\mathrm{II}}$ sites, and oxygen atoms occupy the $\mathrm{X}$ sites. Minor $\mathrm{ZrO}_{2}$ solubility is generally observed in apatite formed by reactions in TBCs $[6,8,29]$. Variations in the Ca:RE ratio are accommodated by introducing vacancies on the $\mathrm{X}$ site $\left(\mathrm{CaO}\right.$-rich) or the cation sites $\left(\mathrm{REO}_{1.5}\right.$-rich), as elaborated below. These coupled substitutions produce a notional stability range between $\mathrm{Ca}_{4} \mathrm{RE}_{6}\left(\mathrm{SiO}_{4}\right)_{6} \mathrm{O}$ and $\mathrm{RE}_{9.33}\left(\mathrm{SiO}_{4}\right)_{6} \mathrm{O}_{2}$. Alternately, oxygen interstitials could yield $\mathrm{RE}_{10}\left(\mathrm{SiO}_{4}\right)_{6} \mathrm{O}_{3}$ [30], although there is less evidence for this mechanism in the literature.

In the $\mathrm{CaO}-\mathrm{SiO}_{2}-\mathrm{REO}_{1.5}$ systems neither the $\mathrm{YO}_{1.5^{-}}$nor $\mathrm{GdO}_{1.5}$-based apatite is stable over the entire range allowed by the crystal chemistry. The $\mathrm{YO}_{1.5^{-}}$and $\mathrm{GdO}_{1.5}$-bearing apatites are stable from $\mathrm{Ca}_{2.5} \mathrm{Y}_{7.5}\left(\mathrm{SiO}_{4}\right)_{6} \mathrm{O}_{1.75}$ to $\mathrm{Ca}_{0.5} \mathrm{Y}_{9}\left(\mathrm{SiO}_{4}\right)_{6} \mathrm{O}_{2}$ [17] and $\mathrm{Ca}_{2.75} \mathrm{Gd}_{7.25}\left(\mathrm{SiO}_{4}\right)_{6} \mathrm{O}_{1.625}$ to $\mathrm{Gd}_{9.33}\left(\mathrm{SiO}_{4}\right)_{6} \mathrm{O}_{2}$, respectively. In the ternary equilibria there appears to be a strong preference for the $\mathrm{Ca}_{2} \mathrm{RE}_{8}\left(\mathrm{SiO}_{4}\right)_{6} \mathrm{O}_{2}$ stoichiometry (i.e. the composition without structural defects).

The apatite formed by reactions with the pure $\mathrm{REO}_{1.5}$, Table 6 and Figure 6(a), is near the nominal $\mathrm{Ca}_{2} \mathrm{RE}_{8}\left(\mathrm{SiO}_{4}\right)_{6} \mathrm{O}_{2}$ stoichiometry indicating that deposits with $\mathrm{Si}$ Ca ratios between 1.4 and 4.7 do not influence the $\mathrm{Si}: \mathrm{Ca}$ ratio in the apatite. Conversely, in systems containing $\mathrm{ZrO}_{2}$ the $\mathrm{CaO}$ content in the apatite increases with the $\mathrm{CaO}$ concentration in the deposit. $\mathrm{Gd}_{2} \mathrm{Zr}_{2} \mathrm{O}_{7}$ and $\mathrm{Y}_{4} \mathrm{Zr}_{3} \mathrm{O}_{12}$ react with $\mathrm{C}_{15} \mathrm{~A}_{15} \mathrm{~S}_{70}$ to produce $\mathrm{Ca}_{2} \mathrm{RE}_{8}\left(\mathrm{SiO}_{4}\right)_{6} \mathrm{O}_{2}$ while apatite formed by reactions with $\mathrm{C}_{36} \underline{\mathrm{A}}_{14} \underline{\mathrm{S}_{50}} \underline{\text { contains }} 50 \%$ more $\mathrm{CaO}$. The latter $\mathrm{CaO}$ concentration is above the $\mathrm{CaO}$ saturation limit for apatite in the $\mathrm{CaO}-\mathrm{SiO}_{2}-\mathrm{REO}_{1.5}$ ternaries and is likely facilitated by coupled, 
charge neutral substitution_of $\mathrm{Ca}^{2+}: \mathrm{Y}^{3+}$ and $\mathrm{Zr}^{4+}: \mathrm{Y}^{3+}$ in the apatite structure, consistent with . the trends in Figure 6.

The implication is that apatite-forming reaction consume more $\mathrm{CaO}$ from the melt (per mole of $\mathrm{REO}_{1.5}$ ) if $\mathrm{REO}_{1.5}$ is supplied by the dissolution of a $\mathrm{RE}$ zirconate than a $\mathrm{ZrO}_{2}$-free coating (e.g., pure $\mathrm{REO}_{1.5}$, silicates, aluminates). This result illustrates the delicate balance between various factors influencing the overall reaction mass balance.

\subsection{Reprecipitated $\mathrm{ZrO}_{2}$}

The $\mathrm{REO}_{1.5}$ solubility in fluorite or $\mathrm{t}-\mathrm{ZrO}_{2}$ (i.e the $\triangle \mathrm{REO}{ }_{1.5}$ between the TBO and reprecipitated $\mathrm{ZrO}_{2}$ phase) has previously been identified as a key indicator of the effectiveness of reactive crystallization to consume silicate melts $[7,11,12]$. Reactions with a small $\Delta \mathrm{REO}_{1.5}$ will produce less apatite than those with a larger $\triangle \mathrm{REO}_{1.5}$. The equilibrium $\mathrm{REO}_{1.5}$ concentration in the reprecipitated phase is a manifestation of (i) the relative driving force for apatite crystallization in a given system, which increases with $\mathrm{RE}^{3+}$ size [31], (ii) the stability of the fluorite phase (inversely related to $\mathrm{RE}^{3+}$ size [32]), and (iii) the $\mathrm{REO}_{1.5}$ solubility in the melt (decreasing with increasing $\mathrm{RE}^{3+}$ size, discussed above). Based on these factors, $\triangle \mathrm{REO}_{1.5}$ increases with the $\mathrm{RE}^{3+}$ size (c.f. $\mathrm{Yb}, \mathrm{Y}$, and $\mathrm{Gd}$ data for $\mathrm{C}_{33} \mathrm{M}_{9} \mathrm{~A}_{13} \mathrm{~S}_{45}$ in Figure 7).

This study extends the prior understanding by determining the influence of the melt composition on the $\Delta \mathrm{REO}_{1.5}$ trends for the zirconates. For each deposit, the $\Delta \mathrm{GdO}_{1.5}$ for $\underline{\mathrm{Gd}}_{2} \underline{\mathrm{Zr}}_{2} \underline{\mathrm{O}}_{7}$ is larger than the $\Delta \mathrm{YO}_{1.5}$ for $\mathrm{Y}_{4} \underline{\mathrm{Zr}}_{3} \underline{\mathrm{O}}_{12}$, confirming that the $\mathrm{RE}^{3+}$ cation size trend extends to a range of melts. Additionally, the $\mathrm{REO}_{1.5}$ concentration in the $\mathrm{ZrO}_{2}$ phase is inversely proportional to the $\mathrm{SiO}_{2}$ content in the melt $\left(\mathrm{C}_{33} \mathrm{M}_{9} \mathrm{~A}_{13} \mathrm{~S}_{45} \rightarrow \mathrm{C}_{36} \mathrm{~A}_{14} \mathrm{~S}_{50} \rightarrow \mathrm{C}_{24} \mathrm{~A}_{17} \mathrm{~S}_{59}\right)$, Figure 8 . $\underline{\text { For } \mathrm{GdO}_{1.5}}$, the larger jump between $\mathrm{C}_{33} \mathrm{M}_{9} \mathrm{~A}_{13} \mathrm{~S}_{45}$ and $\mathrm{C}_{36} \mathrm{~A}_{14} \mathrm{~S}_{50}$ corresponds to the transition

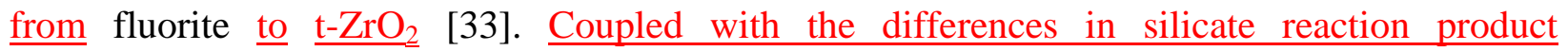
predominance, coatings based on $\mathrm{GdO}_{1.5}$ offer improved melt crystallization efficiently than $\mathrm{YO}_{1.5}$; the efficiency increases with the $\mathrm{SiO}_{2}$ content in the deposit.

\subsubsection{3 $\quad \mathrm{REO}_{1.5}$ Solubility in $\mathrm{ZrSiO}_{4}$}

The zircon formed by reaction with $7 \mathrm{YSZ}, \mathrm{Y}_{4} \mathrm{Zr}_{3} \mathrm{O}_{12}$, or $\mathrm{Gd}_{2} \mathrm{Zr}_{2} \mathrm{O}_{7}$ contained between 1 and $3 \mathrm{~mol} \% \mathrm{REO}_{1.5}$, Table 5. This solubility is notable because it could influence on the phase evolution pathway. It was previously suggested that following YSZ exposure to volcanic-type deposits, zircon crystallizes once YSZ dissolves in the melt [14] and that the $\mathrm{YO}_{1.5}$ remains dissolved in the melt. However, the $\mathrm{YO}_{1.5}$ solubility observed in the present study accounts for 
over sixty percent of the $\mathrm{YO}_{1.5}$ in $7 \mathrm{YSZ}$. Therefore, kinetic hindrances associated with the selective removal of $\mathrm{YO}_{1.5}$ are less likely to play a role in zircon.

The solubility of $\mathrm{REO}_{1.5}$ in zircon has been studied extensively due to its importance in geochronology [34]. Natural zircons contain low concentrations of $\mathrm{REO}_{1.5}$ and $\mathrm{P}_{2} \mathrm{O}_{5}$ consistent with coupled $\mathrm{P}^{5+}: \mathrm{Si}^{4+}$ and $\mathrm{RE}^{3+}: \mathrm{Zr}^{4+}$ substitutions to maintain charge neutrality. However, the absence of phosphorus in this study suggests that another mechanism facilitates the $\operatorname{RE}^{3+}: \mathrm{Zr}^{4+}$ substitution._The zircon structure is composed of $\mathrm{SiO}_{4}$ tetrahedra and $\mathrm{ZrO}_{8}$ dodecahedra alternating along the c-axis; each oxygen is bonded to Si. Unlike the apatite structure, there are no 'ionic' oxygen sites. Oxygen vacancies are therefore unlikely due to the associated vacancy energies and relative instability of the $\mathrm{SiO}_{3}{ }^{2-}$ group [35]. Likewise, $\mathrm{Si}$ vacancies or cation interstitials are unfavorable due to the associated strains in the structures. Nonetheless, other groups have reported $\mathrm{REO}_{1.5}$ solubility in zircon without adding phosphorous for charge compensation $[35,36]$. The leading hypothesis is that, in the absence of $\mathrm{P}$, selective protonation of oxygen in the nominally anhydrous $\mathrm{ZrSiO}_{4}$ occurs in conjunction with the $\mathrm{REO}_{1.5}$ solubility. Limited substitution of $\mathrm{AlO}_{1.5}$ for $\mathrm{SiO}_{2}$ may also contribute to the observed non-stoichiometry.

\subsubsection{Implications for developing CMAS degradation models}

Due to the systematic changes in reactivity illustrated by this study, it is important to consider a variety of deposit compositions when evaluating TBC performance. Notably, none of the TBOs tested exhibits optimal behavior over the entire range of deposit compositions. Demonstrating that a coating material/architecture is resistant to degradation by a single synthetic sand, dust, or ash composition is likely insufficient to guarantee performance. However, the wide variety of 'representative' compositions makes it impractical to experimentally investigate all potential interactions with a menu of candidate coating compositions.

Instead, the problem is better viewed in the context of a broader modeling framework to elucidate the influence of deposit composition variations, including the role minor deposit constituents $s_{2}$ on the anticipated performance of a TBC system. The complete framework would couple thermodynamic and kinetics descriptions of the infiltration and reaction dynamics with thin-film mechanics models. Ideally, existing melt infiltration models $[4,13]$ could be combined with phase equilibrium insights and descriptions of the crystallization kinetics to determine the time dependent infiltration depth. The reaction layer thickness could then be fed into mechanics models describing TBC cracking and delamination under thermo-cyclic stresses $[2,4,37,38]$ to 
determine the likelihood of failure for a given TBC architecture exposed to an arbitrary silicate deposit.

The key element of this framework is a thermodynamic database capable of predicting the wide variety of intrinsic and reactive crystallization products observed upon CMAS-TBC interaction. Owing to their basis in slag chemistry, existing databases (e.g., FactSage FToxid [20] or Thermo-Calc SLAG4) effectively capture the melting and crystallization behavior of the deposits but not the interaction with TBCs. The Thermo-Calc TCOX6 $\underline{\text { database [39] covers some }}$ TBC constituents (i.e. $\mathrm{Y}$ and $\mathrm{Zr}$ ) but does not include adequate descriptions of all potential reaction products. Based on the results of this study, the existing databases should be extended to capture (i) the differences in the solubility of various REO 1.5 in the silicate melt, (ii) the relative

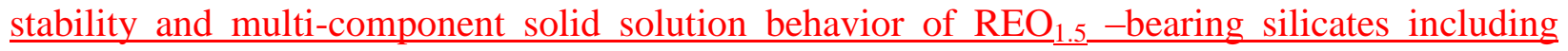
apatite and garnet, (iii) the REO 1.5 partitioning between fluorite and crystalline silicates, and (iv) the transition between $\mathrm{ZrO}_{2}$ precipitation and zircon crystallization for systems containing various $\mathrm{REO}_{1.5}$. To support these efforts, additional experimental phase equilibrium and

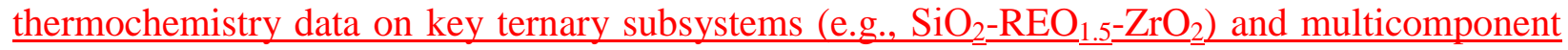
melts and reaction products (e.g. C(M,F)AS+RE+Zr including quaternary and quinary phases) is needed.

\section{CONCLUSIONS}

The overarching conclusion is that the reactions between candidate thermal barrier oxides and molten silicates are strongly influenced by the composition of the deposit, the ratio of $\mathrm{ZrO}_{2}: \mathrm{REO}_{1.5}$ in the TBO, and the identity of the $\mathrm{REO}_{1.5}$. The results make it clear that the underlying multi-component phase equilibria must be considered when developing and evaluating mitigation strategies. Key conclusions include:

- Reactive crystallization depletes $\mathrm{SiO}_{2}$ from the residual melt. $\mathrm{CaO}, \mathrm{MgO}$, and $\mathrm{AlO}_{1.5}$, are enriched, even when CaO-bearing apatite is formed. Due to changes in viscosity, composition evolution is expected to accelerate infiltration into a porous TBC.

- The higher equilibrium $\mathrm{YO}_{1.5}$ solubility in both the residual melt and reprecipitated fluorite reduces the efficacy of crystallization reactions for $\mathrm{YO}_{1.5}$ - compared to $\mathrm{GdO}_{1.5}$ based TBCs.

- Apatite and zircon are the predominant silicate reaction products. Apatite was observed as an equilibrium reaction product for over the entire range of deposit $\mathrm{Si}$ :Ca ratios 
studied. Zircon only forms for $\mathrm{SiO}_{2}$-rich deposits; the minimum $\mathrm{SiO}_{2}$ content to precipitate zircon is influenced by the $\mathrm{REO}_{1.5}$ content in the system. $\mathrm{YO}_{1.5}$ is more likely than $\mathrm{GdO}_{1.5}$ to partition into other crystalline silicates including yttrium disilicate, garnet, and silicocarnotite.

- Coupled $\mathrm{Ca}^{2+}: \mathrm{RE}^{3+}$ and $\mathrm{Zr}^{4+}: \mathrm{RE}^{3+}$ substitutions allow apatite precipitation to capture more $\mathrm{CaO}$ from the melt in systems containing $\mathrm{ZrO}_{2}$. This effect is most pronounced for deposits initially containing a high $\mathrm{CaO}$ concentration.

- The addition of $\mathrm{MgO}$ increased the variety of reactive and intrinsic crystallization products. The effect was more pronounced in systems with little or no residual melt.

Ongoing efforts focus on integrating these findings into thermodynamic databases that, as part of a framework with kinetic and mechanics models, will improve the capability to predict TBC performance.

\section{ACKNOWLEDGEMENTS}

This investigation was supported by the Office of Navy Research under STTR Phase II N00014-12-M-0340 (with Questek Innovations), and ONR grant N00014-16-1-2702, both monitored by Dr. David Shifler. The work made use of the MRL Shared Experimental Facilities supported by the MRSEC Program of the NSF under Award No. DMR 1121053; a member of the NSF-funded Materials Research Facilities Network (www.mrfn.org). The funding agencies were not involved in the study design, the collection, analysis and interpretation of the data, or the decision to publish. The authors are grateful to Drs. G.G.E Seward, E. Zaleski, and R.W. Jackson (UCSB) for helpful discussions and assistance EPMA measurements, preparing the CMAS powders, and performing FactSage calculations, respectively.

\section{REFERENCES}

[1] A.G. Evans, D.R. Clarke, C.G. Levi. The influence of oxides on the performance of advanced gas turbines, J. Eur. Ceram. Soc. 28 (2008) 1405-1419.

[2] C.G. Levi, J.W. Hutchinson, M.-H. Vidal-Sétif, C.A. Johnson. Environmental degradation of thermal-barrier coatings by molten deposits, MRS Bulletin 37 (2012) 932-941.

[3] W.J. Song, Y. Lavallee, K.U. Hess, U. Kueppers, C. Cimarelli, D.B. Dingwell. Volcanic ash melting under conditions relevant to ash turbine interactions, Nat Commun 7 (2016).

[4] R.W. Jackson, E.M. Zaleski, D.L. Poerschke, B.T. Hazel, M.R. Begley, C.G. Levi. Interaction of molten silicates with thermal barrier coatings under temperature gradients, Acta Mater. 89 (2015) 396-407. 
[5] A.G. Evans, J.W. Hutchinson. The mechanics of coating delamination in thermal gradients, Surf. Coat. Technol. 201 (2007) 7905-7916.

[6] S. Kramer, J. Yang, C.G. Levi. Infiltration-inhibiting reaction of gadolinium zirconate thermal barrier coatings with CMAS melts, J. Am. Ceram. Soc. 91 (2008) 576-583.

[7] D.L. Poerschke, C.G. Levi. Effects of cation substitution and temperature on the interaction between thermal barrier oxides and molten CMAS, J. Eur. Ceram. Soc. 35 (2015) 681-691.

[8] P. Mechnich, W. Braue. Volcanic Ash-Induced Decomposition of EB-PVD $\mathrm{Gd}_{2} \mathrm{Zr}_{2} \mathrm{O}_{7}$ Thermal Barrier Coatings to Gd-Oxyapatite, Zircon, and Gd, Fe-Zirconolite, J. Am. Ceram. Soc. 96 (2013) 1958-1965.

[9] J.M. Drexler, C.-H. Chen, A.D. Gledhill, K. Shinoda, S. Sampath, N.P. Padture. Plasma sprayed gadolinium zirconate thermal barrier coatings that are resistant to damage by molten Ca-Mg-Al-silicate glass, Surf. Coat. Technol. 206 (2012) 3911-3916.

[10] N.K. Eils, P. Mechnich, W. Braue. Effect of CMAS Deposits on MOCVD Coatings in the System $\mathrm{Y}_{2} \mathrm{O}_{3}-\mathrm{ZrO}_{2}$ : Phase Relationships, J. Am. Ceram. Soc. 96 (2013) 3333-3340.

[11] D.L. Poerschke, D.D. Hass, S. Eustis, G.G.E. Seward, J.S. Van Sluytman, C.G. Levi. Stability and CMAS Resistance of Ytterbium-Silicate/Hafnate EBCs/TBC for SiC Composites, J. Am. Ceram. Soc. 98 (2015) 278-286.

[12] D.L. Poerschke, G.G.E. Seward, C.G. Levi. Influence of Yb:Hf Ratio on Ytterbium Hafnate/Molten Silicate (CMAS) Reactivity, J. Am. Ceram. Soc. 99 (2016) 651-659.

[13] S. Krämer, J. Yang, C.G. Levi, C.A. Johnson. Thermochemical Interaction of Thermal Barrier Coatings with Molten $\mathrm{CaO}-\mathrm{MgO}-\mathrm{Al}_{2} \mathrm{O}_{3}-\mathrm{SiO}_{2}$ (CMAS) Deposits, J. Am. Ceram. Soc. 89 (2006) 3167-3175.

[14] P. Mechnich, W. Braue, U. Schulz. High-Temperature Corrosion of EB-PVD Yttria Partially Stabilized Zirconia Thermal Barrier Coatings with an Artificial Volcanic Ash Overlay, J. Am. Ceram. Soc. 94 (2011) 925-931.

[15] M.H. Vidal-Setif, C. Rio, D. Boivin, O. Lavigne. Microstructural characterization of the interaction between 8YPSZ (EB-PVD) thermal barrier coatings and a synthetic CAS, Surf. Coat. Technol. 239 (2014) 41-48.

[16] E.M. Zaleski, C. Ensslen, C.G. Levi. Melting and Crystallization of Silicate Systems Relevant to Thermal Barrier Coating Damage, J. Am. Ceram. Soc. 98 (2015) 1642-1649.

[17] D.L. Poerschke, T.L. Barth, O. Fabrichnaya, C.G. Levi. Phase equilibria and crystal chemistry in the calcia-silica-yttria system, J. Eur. Ceram. Soc. 36 (2016) 1743-1754.

[18] M.P. Borom, C.A. Johnson, L.A. Peluso. Role of environmental deposits and operating surface temperature in spallation of air plasma sprayed thermal barrier coatings, Surf. Coat. Technol. 86 (1996) 116-126.

[19] H. Mao, M. Hillert, M. Selleby, B. Sundman. Thermodynamic Assessment of the CaO$\mathrm{Al}_{2} \mathrm{O}_{3}-\mathrm{SiO}_{2}$ System, J. Am. Ceram. Soc. 89 (2006) 298-308.

[20] C.W. Bale, E. Belisle, P. Chartrand, S.A. Decterov, G. Eriksson, A. Gheribi, K. Hack, I.H. Jung, J. Melancon, A.D. Pelton, S. Petersen, C. Robelin. Recent Developments in Factsage Thermochemical Software and Databases, Celebrating the Megascale: Proceedings of the 
Extraction and Processing Division Symposium on Pyrometallurgy in Honor of David G.C. Robertson (2014) 141-148.

[21] K.M. Grant, S. Krämer, G.G.E. Seward, C.G. Levi. Calcium-magnesium alumino-silicate interaction with yttrium monosilicate environmental barrier coatings, J. Am. Ceram. Soc. 93 (2010) 3504-3511.

[22] A. Fluegel. Glass viscosity calculation based on a global statistical modelling approach, Glass Technol.-Eur. J. Glass Sci. Technol. Part A 48 (2007) 13-30.

[23] M.T. Wang, J.S. Cheng, M. Li, F. He, W. Deng. Viscosity and thermal expansion of sodalime-silica glass doped with Gd2O3 and Y2O3, Solid State Sci. 14 (2012) 1233-1237.

[24] D. Giordano, J.K. Russell, D.B. Dingwell. Viscosity of magmatic liquids: A model, Earth Planet. Sci. Lett. 271 (2008) 123-134.

[25] C.W. Ponader, G.E. Brown. Rare-Earth Elements in Silicate Glass Melt Systems .1. Effects of Composition on the Coordination Environments of La, Gd, and Yb, Geochim.

Cosmochim. Acta 53 (1989) 2893-2903.

[26] J. Wang, W.S. Brocklesby, J.R. Lincoln, J.E. Townsend, D.N. Payne. Local Structures of Rare-Earth Ions in Glasses - the Crystal-Chemistry Approach, J. Non-Cryst. Solids 163 (1993) 261-267.

[27] N. Chellah, M.-H. Vidal-Sétif, C. Petitjean, P.-J. Panteix, C. Rapin, M. Vilasi. CalciumMagnesium-Alumino-Silicate (CMAS) degradation of thermal barrier coatings: solubility of different oxides from $\mathrm{ZrO}_{2}-\mathrm{Nd}_{2} \mathrm{O}_{3}$ system in a model CMAS. HTCPM8. Les Embiez, France, 2012.

[28] J.M. Drexler, A.L. Ortiz, N.P. Padture. Composition effects of thermal barrier coating ceramics on their interaction with molten Ca-Mg-Al-silicate (CMAS) glass, Acta Mater. 60 (2012) 5437-5447.

[29] H. Zhao, C.G. Levi, H.N.G. Wadley. Molten Silicate Interactions with Thermal Barrier Coatings, Surf. Coat. Technol. 251 (2014) 74-86.

[30] S. Nakayama, T. Kageyama, H. Aono, Y. Sadaoka. Ionic-Conductivity of Lanthanoid Silicates, $\mathrm{Ln}_{10}(\mathrm{SiO} 4)_{6} \mathrm{O}_{3}(\mathrm{Ln}=\mathrm{La}, \mathrm{Nd}, \mathrm{Sm}, \mathrm{Gd}, \mathrm{Dy}, \mathrm{Y}, \mathrm{Ho}, \mathrm{Er}$ and $\mathrm{Yb})$, J. Mater. Chem. 5 (1995) 1801-1805.

[31] A.S. Risbud, K.B. Helean, M.C. Wilding, P. Lu, A. Navrotsky. Enthalpies of formation of lanthanide oxyapatite phases, J. Mater. Res. 16 (2001) 2780-2783.

[32] E.R. Andrievskaya. Phase equilibria in the refractory oxide systems of zirconia, hafnia and yttria with rare-earth oxides, J. Eur. Ceram. Soc. 28 (2008) 2363-2388.

[33] O. Fabrichnaya, C. Wang, M. Zinkevich, C.G. Levi, F. Aldinger. Phase equilibria and thermodynamic properties of the $\mathrm{ZrO}_{2}-\mathrm{GdO}_{1.5}-\mathrm{YO}_{1.5}$ system, J. Phase Equilib. Diffus. 26 (2005) 591-604.

[34] P.W.O. Hoskin, T.R. Ireland. Rare earth element chemistry of zircon and its use as a provenance indicator, Geology 28 (2000) 627-630. 
[35] J.M. Hanchar, R.J. Finch, P.W.O. Hoskin, E.B. Watson, D.J. Cherniak, A.N. Mariano. Rare earth elements in synthetic zircon: Part 1. Synthesis, and rare earth element and phosphorus doping, Am. Mineral. 86 (2001) 667-680.

[36] J.C.M. De Hoog, C.J. Lissenberg, R.A. Brooker, R. Hinton, D. Trail, E. Hellebrand, Eimf. Hydrogen incorporation and charge balance in natural zircon, Geochim. Cosmochim. Acta 141 (2014) 472-486.

[37] C. Mercer, S. Faulhaber, A.G. Evans, R. Darolia. A delamination mechanism for thermal barrier coatings subject to calcium-magnesium-alumino-silicate (CMAS) infiltration, Acta Mater. 53 (2005) 1029-1039.

[38] S. Krämer, S. Faulhaber, M. Chambers, D.R. Clarke, C.G. Levi, J.W. Hutchinson, A.G. Evans. Mechanisms of cracking and delamination within thick thermal barrier systems in aero-engines subject to calcium-magnesium-alumino-silicate (CMAS) penetration, Mater. Sci. Eng., A 490 (2008) 26-35.

[39] Thermo-Calc Software AB. TCOX6-TCS, Metal Oxide Solutions Database, v6.x 2015. 


\section{TABLES}

Table 1: Reaction Product Identities

\begin{tabular}{|c|c|c|c|}
\hline Type & Name & Abbreviation & Nominal Formula \\
\hline Reprecipitation & $\begin{array}{c}\text { Fluorite } \\
\text { Tetragonal } \mathrm{ZrO}_{2}\end{array}$ & $\begin{array}{l}F \\
Z\end{array}$ & $\begin{array}{l}(\mathrm{Zr}, \mathrm{RE}, \mathrm{Ca}) \mathrm{O}_{1 . \mathrm{x}} \\
(\mathrm{Zr}, \mathrm{RE}, \mathrm{Ca}) \mathrm{O}_{1 . \mathrm{x}}\end{array}$ \\
\hline $\begin{array}{c}\text { Reactive } \\
\text { Crystallization }\end{array}$ & $\begin{array}{c}\text { Zircon } \\
\text { Apatite } \\
\text { Garnet } \\
\text { Yttrium Disilicate } \\
\text { Silicocarnotite } \\
\end{array}$ & $\begin{array}{l}\text { ZS } \\
\text { Ap } \\
\text { Gar } \\
\text { YDS } \\
\text { SC } \\
\end{array}$ & $\begin{array}{c}\mathrm{ZrSiO}_{4} \\
(\mathrm{Ca}, \mathrm{RE})_{4}(\mathrm{RE}, \mathrm{Zr})_{6}\left(\mathrm{SiO}_{4}\right)_{6} \mathrm{O}_{2} \\
(\mathrm{Ca}, \mathrm{RE}, \mathrm{Zr})_{3}(\mathrm{Mg}, \mathrm{Al})_{2}(\mathrm{Si}, \mathrm{Al})_{3} \mathrm{O}_{12} \\
\mathrm{Y}_{2} \mathrm{Si}_{2} \mathrm{O}_{7} \\
\mathrm{Ca}_{3} \mathrm{RE}_{2} \mathrm{Si}_{3} \mathrm{O}_{12}\end{array}$ \\
\hline $\begin{array}{c}\text { Intrinsic } \\
\text { Crystallization }\end{array}$ & $\begin{array}{c}\text { Anorthite } \\
\text { Diopside } \\
\text { Cristobalite, Tridymite } \\
\text { (Pseudo-)wollastonite } \\
\text { Melilite } \\
\text { Spinel }\end{array}$ & $\begin{array}{c}\mathrm{An} \\
\mathrm{Di} \\
\mathrm{SiO}_{2} \\
\mathrm{CS} \\
\mathrm{Mel} \\
\mathrm{Sp} \\
\end{array}$ & $\begin{array}{c}\mathrm{CaAl}_{2} \mathrm{Si}_{2} \mathrm{O}_{8} \\
\mathrm{CaMgSi}_{2} \mathrm{O}_{6} \\
\mathrm{SiO}_{2} \\
\mathrm{CaSiO}_{3} \\
(\mathrm{Ca})_{2}(\mathrm{Al}, \mathrm{Mg})(\mathrm{Al}, \mathrm{Si}) \mathrm{SiO}_{7} \\
\mathrm{MgAl}_{2} \mathrm{O}_{7}\end{array}$ \\
\hline
\end{tabular}

Table 2: Synthetic Silicate Deposits

\begin{tabular}{|c|c|c|c|c|c|}
\hline $\begin{array}{c}\text { Composition } \\
(\mathrm{mol} \%)\end{array}$ & $\begin{array}{l}\text { Si:Ca } \\
\text { Ratio }\end{array}$ & $\begin{array}{c}T_{I M}(\text { Exp. }) \\
{[16]}\end{array}$ & $\begin{array}{c}\mathrm{T}_{\mathrm{S}} \\
\text { (Calc) }\end{array}$ & $\begin{array}{c}\mathbf{T}_{\mathbf{L}} \\
\text { (Calc) }\end{array}$ & $\begin{array}{l}1300^{\circ} \mathrm{C} \mathrm{Eq} . \\
\text { (Calc) }\end{array}$ \\
\hline $\mathrm{C}_{33} \mathrm{M}_{9} \mathrm{~A}_{13} \mathrm{~S}_{45}$ & 1.4 & $1233^{\circ} \mathrm{C}$ & $1229^{\circ} \mathrm{C}$ & $1258^{\circ} \mathrm{C}$ & Liquid \\
\hline $\mathrm{C}_{36} \mathrm{~A}_{14} \mathrm{~S}_{50}$ & 1.4 & $1140^{\circ} \mathrm{C}$ & $1184^{\circ} \mathrm{C}$ & $1363^{\circ} \mathrm{C}$ & $\begin{array}{c}\mathrm{Liq}+\mathrm{CS} \\
\left(\mathrm{Liq}=\mathrm{C}_{237} \mathrm{~A}_{163} \mathrm{~S}_{50}\right)\end{array}$ \\
\hline $\mathrm{C}_{24} \mathrm{~A}_{17} \mathrm{~S}_{59}$ & 2.5 & $1125^{\circ} \mathrm{C}$ & $1184^{\circ} \mathrm{C}$ & $1184^{\circ} \mathrm{C}$ & Liquid \\
\hline $\mathrm{C}_{15} \mathrm{~A}_{15} \mathrm{~S}_{70}$ & 4.7 & $1140^{\circ} \mathrm{C}$ & $1184^{\circ} \mathrm{C}$ & $1479^{\circ} \mathrm{C}$ & $\begin{array}{c}\mathrm{Liq}+\mathrm{SiO}_{2}+\mathrm{An}^{*} \\
\left(\mathrm{Liq}=\mathrm{C}_{18.8} \mathrm{~A}_{18.1} \mathrm{~S}_{63.1}\right)\end{array}$ \\
\hline
\end{tabular}

* Calculated anorthite fraction is less than $1 \%$.

Table 3: Observed Equilibrium phases at $1300^{\circ} \mathrm{C}$

\begin{tabular}{|c|c|c|c|c|}
\hline TBO & $\mathrm{C}_{33} \mathrm{M}_{9} \mathrm{~A}_{13} \mathrm{~S}_{45}$ & $\mathrm{C}_{36} \mathrm{~A}_{14} \mathrm{~S}_{50}$ & $\mathrm{C}_{24} \mathrm{~A}_{17} \mathrm{~S}_{59}$ & $\mathrm{C}_{15} \mathrm{~A}_{15} \mathrm{~S}_{70}$ \\
\hline-- & Liq & $\mathrm{Liq}+\mathrm{CS}$ & Liq & $\mathrm{Liq}+\mathrm{SiO}_{2}$ \\
\hline $\mathrm{ZrO}_{2}$ & $\mathrm{Liq}+\mathrm{Z}$ & $\mathrm{Liq}+\mathrm{Z}$ & $\mathrm{Liq}+\mathrm{tZ}+\mathrm{ZS}+\mathrm{An}$ & $\mathrm{Liq}+\mathrm{An}+\mathrm{ZS}^{*}$ \\
\hline 7YSZ & $\mathrm{Liq}+\mathrm{Z}$ & $\mathrm{Liq}+\mathrm{Z}$ & $\mathrm{Liq}+\mathrm{tZ}+\mathrm{ZS}$ & $\mathrm{Liq}+\mathrm{ZS}^{*}$ \\
\hline $\mathrm{Y}_{4} \mathrm{Zr}_{3} \mathrm{O}_{12}$ & $\mathrm{Liq}+\mathrm{F}+\mathrm{Ap}$ & $\mathrm{Liq}+\mathrm{F}+\mathrm{Ap}$ & $\mathrm{Liq}+\mathrm{F}+\mathrm{Ap}$ & $\mathrm{Liq}+\mathrm{Ap}+\mathrm{ZS}^{*}$ \\
\hline $\mathrm{Gd}_{2} \mathrm{Zr}_{2} \mathrm{O}_{7}$ & $\mathrm{Liq}+\mathrm{F}+\mathrm{Ap}$ & $\mathrm{Liq}+\mathrm{tZ}+\mathrm{Ap}$ & $\mathrm{Liq}+\mathrm{tZ}+\mathrm{Ap}+\mathrm{ZS}$ & $\mathrm{Liq}+\mathrm{Ap}+\mathrm{ZS}+\mathrm{An}$ \\
\hline $\mathrm{YO}_{1.5}$ & $\mathrm{Ap}+\mathrm{Mel}+\mathrm{Gar}$ & $\mathrm{Liq}+\mathrm{Ap}+\mathrm{SC}+\mathrm{An}$ & $\mathrm{Liq}+\mathrm{Ap}+\mathrm{An}$ & $\mathrm{Liq}+\mathrm{Ap}+\mathrm{YDS}_{-}^{*}$ \\
\hline $\mathrm{GdO}_{1.5}$ & $\mathrm{Liq}+\mathrm{Ap}+\mathrm{Mel}+\mathrm{Sp}$ & $\mathrm{Liq}+\mathrm{Ap}$ & $\mathrm{Liq}+\mathrm{Ap}+\mathrm{An}$ & $\mathrm{Liq}+\mathrm{Ap}+\mathrm{An}+\mathrm{SiO}_{2}$ \\
\hline
\end{tabular}


Table 4: Measured Glass Compositions (mol\%)*

\begin{tabular}{|c|c|c|c|c|c|c|c|}
\hline \multicolumn{2}{|c|}{ System } & \multirow{2}{*}{$\mathrm{CaO}$} & \multirow{2}{*}{$\mathrm{MgO}$} & \multirow{2}{*}{$\mathrm{AlO}_{1.5}$} & \multirow{2}{*}{$\mathrm{SiO}_{2}$} & \multirow{2}{*}{$\mathrm{REO}_{1.5}$} & \multirow{2}{*}{$\mathrm{ZrO}_{2}$} \\
\hline TBO & Syn. Deposit & & & & & & \\
\hline \multirow{4}{*}{--} & $\mathrm{C}_{33} \mathrm{M}_{9} \mathrm{~A}_{13} \mathrm{~S}_{45}$ & 31.9 & 9.3 & 13.9 & 44.7 & -- & -- \\
\hline & $\mathrm{C}_{36} \mathrm{~A}_{14} \mathrm{~S}_{50}$ & 30.8 & -- & 19.0 & 49.6 & -- & -- \\
\hline & $\mathrm{C}_{24} \mathrm{~A}_{17} \mathrm{~S}_{59}$ & 23.4 & -- & 17.1 & 59.4 & -- & -- \\
\hline & $\mathrm{C}_{15} \mathrm{~A}_{15} \mathrm{~S}_{70}$ & 17.2 & -- & 18.1 & 64.7 & -- & -- \\
\hline \multirow{4}{*}{$\mathrm{ZrO}_{2}$} & $\mathrm{C}_{33} \mathrm{M}_{9} \mathrm{~A}_{13} \mathrm{~S}_{45}$ & 31.4 & 9.0 & 13.6 & 44.3 & -- & 1.6 \\
\hline & $\mathrm{C}_{36} \mathrm{~A}_{14} \mathrm{~S}_{50}$ & 33.9 & -- & 14.7 & 48.8 & -- & 2.3 \\
\hline & $\mathrm{C}_{24} \mathrm{~A}_{17} \mathrm{~S}_{59}$ & 31.7 & -- & 13.9 & 51.4 & -- & 2.5 \\
\hline & $\mathrm{C}_{15} \mathrm{~A}_{15} \mathrm{~S}_{70}$ & 22.0 & -- & 17.3 & 59.6 & -- & 1.0 \\
\hline \multirow{4}{*}{ 7YSZ } & $\mathrm{C}_{33} \mathrm{M}_{9} \mathrm{~A}_{13} \mathrm{~S}_{45}$ & 31.0 & 9.1 & 13.4 & 43.2 & 1.6 & 1.7 \\
\hline & $\mathrm{C}_{36} \mathrm{~A}_{14} \mathrm{~S}_{50}$ & 33.3 & -- & 14.4 & 48.0 & 2.0 & 2.3 \\
\hline & $\mathrm{C}_{24} \mathrm{~A}_{17} \mathrm{~S}_{59}$ & 25.5 & -- & 18.7 & 52.0 & 1.9 & 2.0 \\
\hline & $\mathrm{C}_{15} \mathrm{~A}_{15} \mathrm{~S}_{70}$ & 18.9 & -- & 20.0 & 58.1 & 1.7 & 1.3 \\
\hline \multirow{4}{*}{$\mathrm{Y}_{4} \mathrm{Zr}_{3} \mathrm{O}_{12}$} & $\mathrm{C}_{33} \mathrm{M}_{9} \mathrm{~A}_{13} \mathrm{~S}_{45}$ & 30.9 & 10.4 & 16.0 & 38.8 & 2.8 & 1.1 \\
\hline & $\mathrm{C}_{36} \mathrm{~A}_{14} \mathrm{~S}_{50}$ & 33.7 & -- & 18.4 & 46.8 & 2.3 & 1.6 \\
\hline & $\mathrm{C}_{24} \mathrm{~A}_{17} \mathrm{~S}_{59}$ & 21.5 & -- & 18.7 & 53.6 & 4.3 & 2.0 \\
\hline & $\mathrm{C}_{15} \mathrm{~A}_{15} \mathrm{~S}_{70}$ & 15.5 & -- & 18.1 & 59.4 & 5.2 & 1.7 \\
\hline \multirow{4}{*}{$\mathrm{Gd}_{2} \mathrm{Zr}_{2} \mathrm{O}_{7}$} & $\mathrm{C}_{33} \mathrm{M}_{9} \mathrm{~A}_{13} \mathrm{~S}_{45}$ & 30.3 & 10.4 & 16.1 & 39.9 & 1.9 & 1.4 \\
\hline & $\mathrm{C}_{36} \mathrm{~A}_{14} \mathrm{~S}_{50}$ & 33 & -- & 19 & 44 & 2 & 2 \\
\hline & $\mathrm{C}_{24} \mathrm{~A}_{17} \mathrm{~S}_{59}$ & 24.3 & -- & 18.5 & 51.6 & 3.3 & 2.4 \\
\hline & $\mathrm{C}_{15} \mathrm{~A}_{15} \mathrm{~S}_{70}$ & 14.3 & -- & 18.9 & 62.0 & 3.8 & 1.0 \\
\hline \multirow{4}{*}{$\mathrm{YO}_{1.5}$} & $\mathrm{C}_{33} \mathrm{M}_{9} \mathrm{~A}_{13} \mathrm{~S}_{45}$ & \multicolumn{6}{|c|}{ No Glass } \\
\hline & $\mathrm{C}_{36} \mathrm{~A}_{14} \mathrm{~S}_{50}$ & 35.9 & -- & 22.8 & 38.4 & 2.8 & -- \\
\hline & $\mathrm{C}_{24} \mathrm{~A}_{17} \mathrm{~S}_{59}$ & 25 & -- & 13 & 58 & 4 & -- \\
\hline & $\mathrm{C}_{15} \mathrm{~A}_{15} \mathrm{~S}_{70}$ & 15.4 & - & 20.7 & 59.2 & 4.7 & -- \\
\hline \multirow{4}{*}{$\mathrm{GdO}_{1.5}$} & $\mathrm{C}_{33} \mathrm{M}_{9} \mathrm{~A}_{13} \mathrm{~S}_{45}$ & 18 & 16 & 23 & 41 & 2 & -- \\
\hline & $\mathrm{C}_{36} \mathrm{~A}_{14} \mathrm{~S}_{50}$ & 36 & -- & 20 & 41 & 2 & -- \\
\hline & $\mathrm{C}_{24} \mathrm{~A}_{17} \mathrm{~S}_{59}$ & 22 & -- & 19 & 57 & 3 & -- \\
\hline & $\mathrm{C}_{15} \mathrm{~A}_{15} \mathrm{~S}_{70}$ & 28 & -- & 12 & 55 & 4 & -- \\
\hline
\end{tabular}

* Values reported to $0.1 \mathrm{~mol} \%$ and $1 \mathrm{~mol} \%$ precision measured by EPMA and TEM-EDS, respectively. 
Table 5: Measured $\mathrm{ZrSiO}_{4}$ Compositions (mol\%)*

\begin{tabular}{ccccc}
\hline System & $\mathrm{SiO}_{2}$ & $\mathrm{ZrO}_{2}$ & $\mathrm{REO}_{1.5}$ & $\mathrm{ZrO}_{2}+\mathrm{REO}_{1.5}$ \\
\hline $\mathrm{C}_{24} \mathrm{~A}_{17} \mathrm{~S}_{59}+\mathrm{ZrO}_{2}$ & 49.8 & 49.8 & -- & 49.8 \\
$\mathrm{C}_{24} \mathrm{~A}_{17} \mathrm{~S}_{59}+7 \mathrm{YSZ}$ & 49.8 & 48.1 & 1.8 & 49.9 \\
$\mathrm{C}_{15} \mathrm{~A}_{15} \mathrm{~S}_{70}+7 \mathrm{YSZ}$ & 49.1 & 48.1 & 2.2 & 50.3 \\
$\mathrm{C}_{15} \mathrm{~A}_{15} \mathrm{~S}_{70}+\mathrm{Y}_{4} \mathrm{Zr}_{3} \mathrm{O}_{12}$ & 49.4 & 47.9 & 2.4 & 50.3 \\
$\mathrm{C}_{24} \mathrm{~A}_{17} \mathrm{~S}_{59}+\mathrm{Gd}_{2} \mathrm{Zr}_{2} \mathrm{O}_{7}$ & 49.5 & 48.8 & 1.5 & 50.3 \\
$\mathrm{C}_{15} \mathrm{~A}_{15} \mathrm{~S}_{70}+\mathrm{Gd}_{2} \mathrm{Zr}_{2} \mathrm{O}_{7}$ & 49.7 & 47.6 & 2.7 & 50.3 \\
\hline Total measured $\mathrm{CaO}+\mathrm{AlO}_{1.5}$, not tabulated here, was $0.1 \mathrm{~mol} \%$ to $0.3 \mathrm{~mol} \%$.
\end{tabular}

Table 6: Measured Apatite Compositions (mol\%)*

\section{FIGURES}

Figure 1: Calculated phase equilibria for the (a) $\mathrm{CaO}-\mathrm{AlO}_{1.5}-\mathrm{SiO}_{2}$ system and (b) section at 9 mol\% $\mathrm{MgO}$ in $\mathrm{CaO}-\mathrm{MgO}-\mathrm{AlO}_{1.5}-\mathrm{SiO}_{2}$ system. The liquid field at $1300^{\circ} \mathrm{C}$ (dark shading), phase fields containing liquid (light shading), and synthetic deposit compositions for this study are superimposed on the projected liquidus surface. The relevant eutectic compositions and temperatures are labeled. The effect of $\mathrm{MgO}$ addition on the shape and extent of the liquid field is highlighted in (c). 
Figure 2: BS-SEM micrographs of the synthetic silicate deposit microstructure following equilibration at $1300^{\circ} \mathrm{C}$. Numbers in brackets indicate the $\mathrm{CaO}: \mathrm{SiO}_{2}$ ratio for the overall deposit composition.

Figure 3: BS-SEM micrographs showing the equilibrated microstructures of mixtures of synthetic silicate deposits with $\mathrm{ZrO}_{2}$ and 7YSZ. The figure is arranged in order of increasing $\mathrm{SiO}_{2}$ fraction from top to bottom. Crystalline phases labeled according to Table 1; the dark gray matrix in each micrograph is glass. The contrast of the inset in (d) adjusted to distinguish anorthite and glass. TEM analysis of (f) shown in Figure 4(a).

Figure 4: BF-TEM micrographs showing the structures of $\mathrm{C}_{36} \mathrm{~A}_{14} \mathrm{~S}_{50}$ equilibrated with (a) $7 \mathrm{YSZ}$ or (b) $\mathrm{Gd}_{2} \mathrm{Zr}_{2} \mathrm{O}_{7}$. The twinned microstructure of the $\mathrm{ZrO}_{2}$ grains indicates the tetragonal to monoclinic transformation upon cooling.

Figure 5: BS-SEM micrographs comparing the $\mathrm{Y}_{4} \mathrm{Zr}_{3} \mathrm{O}_{12}$ and $\mathrm{Gd}_{2} \mathrm{Zr}_{2} \mathrm{O}_{7}$ reactivity with synthetic silicate deposits at $1300^{\circ} \mathrm{C}$, arranged with increasing $\mathrm{SiO}_{2}$ content from top to bottom. Apatite is observed for every combination. $\mathrm{ZrO}_{2}$-based reaction products include (a-c,e) fluorite, (d,g,h) $\mathrm{ZrSiO}_{4}$, and (f,g) $\mathrm{t}-\mathrm{ZrO}_{2}$. The dark gray matrix in each micrograph is glass; TEM analysis of (f) shown in Figure 4(b).

Figure 6: The equilibrium (a) $\mathrm{CaO}$ and (b) $\mathrm{ZrO}_{2}$ concentration in apatite increases with the $\mathrm{CaO}$ concentration in the melt for systems containing $\mathrm{ZrO}_{2}$ while those without $\mathrm{ZrO}_{2}$ exhibit constant $\mathrm{CaO}$ content. The incorporation of $\mathrm{ZrO}_{2}$ into the apatite enables the increased $\mathrm{CaO}$ content without incorporating oxygen vacancies leading to (ㄷ) constant oxygen content for all scenarios tested. The shaded bands are based on a linear fit to each data set.

Figure 7: Compositions of fluorite and tetragonal $\mathrm{ZrO}_{2}$ phases illustrating the influence of both $\mathrm{REO}_{1.5}$ identity and deposit composition on the equilibrium reaction products. The data for equivalent experiments using $\mathrm{YbO}_{1.5}-\mathrm{HfO}_{2}$ TBOs was reported previously [12].

Figure 8: The equilibrium $\mathrm{REO}_{1.5}$ concentrations in the residual melt varies as a function of both the reacted TBO and the initial melt composition. Concentrations for all oxides but 7YSZ correspond to $\mathrm{REO}_{1.5}$ saturation limit with respect to apatite precipitation.

Figure 9: BS-SEM micrographs comparing $\mathrm{YO}_{1.5}$ and $\mathrm{GdO}_{1.5}$ reactivity with synthetic silicate deposits at $1300^{\circ} \mathrm{C}$, arranged with increasing $\mathrm{SiO}_{2}$ content from top to bottom. Apatite is observed for every combination. The dark gray matrix in each micrograph except (a) is glass. The contrast in the insets is adjusted to distinguish between the darker phases. TEM characterization revealing additional detail of $(\mathrm{a}, \mathrm{e}, \mathrm{g}, \mathrm{h})$ is shown in Figure 10.

Figure 10: BF-TEM micrographs showing additional detail of $\mathrm{YO}_{1.5}$ and $\mathrm{GdO}_{1.5}$ in equilibrium with various silicate deposits. Note the absence of a residual amorphous phase in (a).

Figure 11: The change (a) $\mathrm{SiO}_{2}$ concentration ${ }_{2}$ (b) $\mathrm{Si}: \mathrm{Ca}$ ratio, and (c) calculated viscosity[24] of the residual melt is a function of the deposit composition and the crystallization products. As discussed in the text, compositions in (a) and (c) are normalized to $\mathrm{SiO}_{2}+\mathrm{CaO}+\mathrm{MgO}+\mathrm{AlO}_{1.5}$. The solid and dotted horizontal lines represent the initial bulk silicate deposit and the initial liquid compositions, respectively. Error bars for the measurements are smaller than the symbols. 
(a) $\mathrm{CaO}-\mathrm{AlO}_{1.5}-\mathrm{SiO}_{2}$ (mol\%)

$\mathrm{CaO}$

$\mathrm{C}_{24} \mathrm{~A}_{17} \mathrm{~S}_{59}$

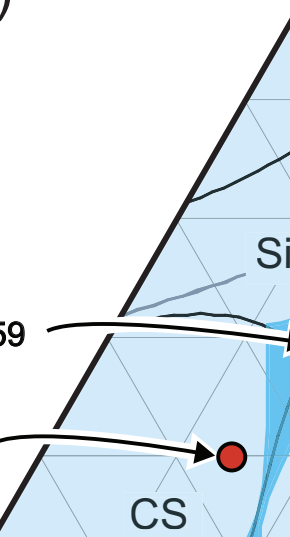

$\mathrm{C}_{36} \mathrm{~A}_{14} \mathrm{~S}_{50}$

$t_{1185^{\circ} \mathrm{C}}$

$\mathrm{C}_{15} \mathrm{~A}_{15} \mathrm{~S}_{70}$

$\mathrm{CA}_{2} \mathrm{~S}_{2}$

CS

$\mathrm{C}_{3} \mathrm{~S}_{2}$
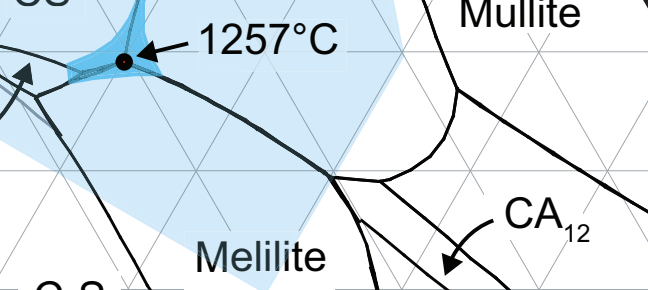

$\mathrm{C}_{2} \mathrm{~S} \quad \begin{aligned} & \text { Melilite } \\ & \left(\mathrm{C}_{2} \mathrm{~A}_{2} \mathrm{~S}\right)\end{aligned}$

Lime

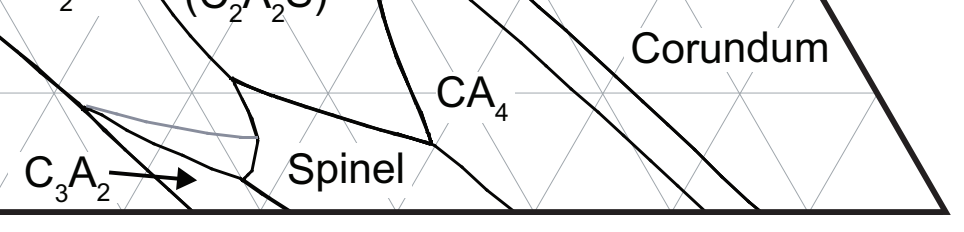

$\mathrm{AlO}_{1.5}$

$\mathrm{SiO}_{2}$

(b) $\mathrm{CAS}+9 \mathrm{~mol} \% \mathrm{MgO}$ (mol\% / 0.91)
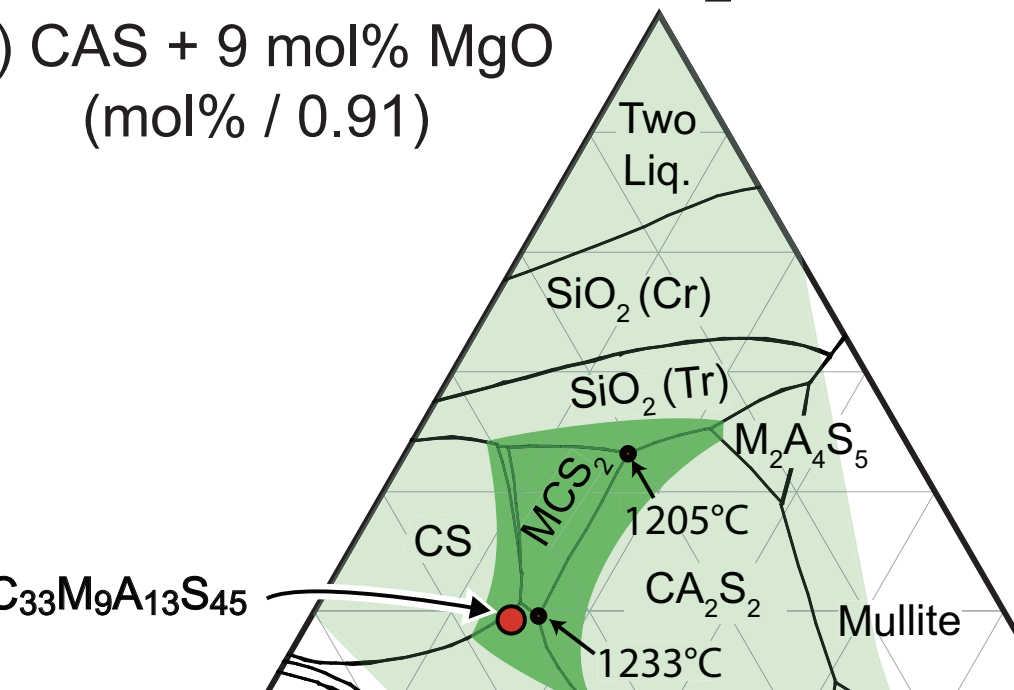

4 $\mathrm{CaO}$
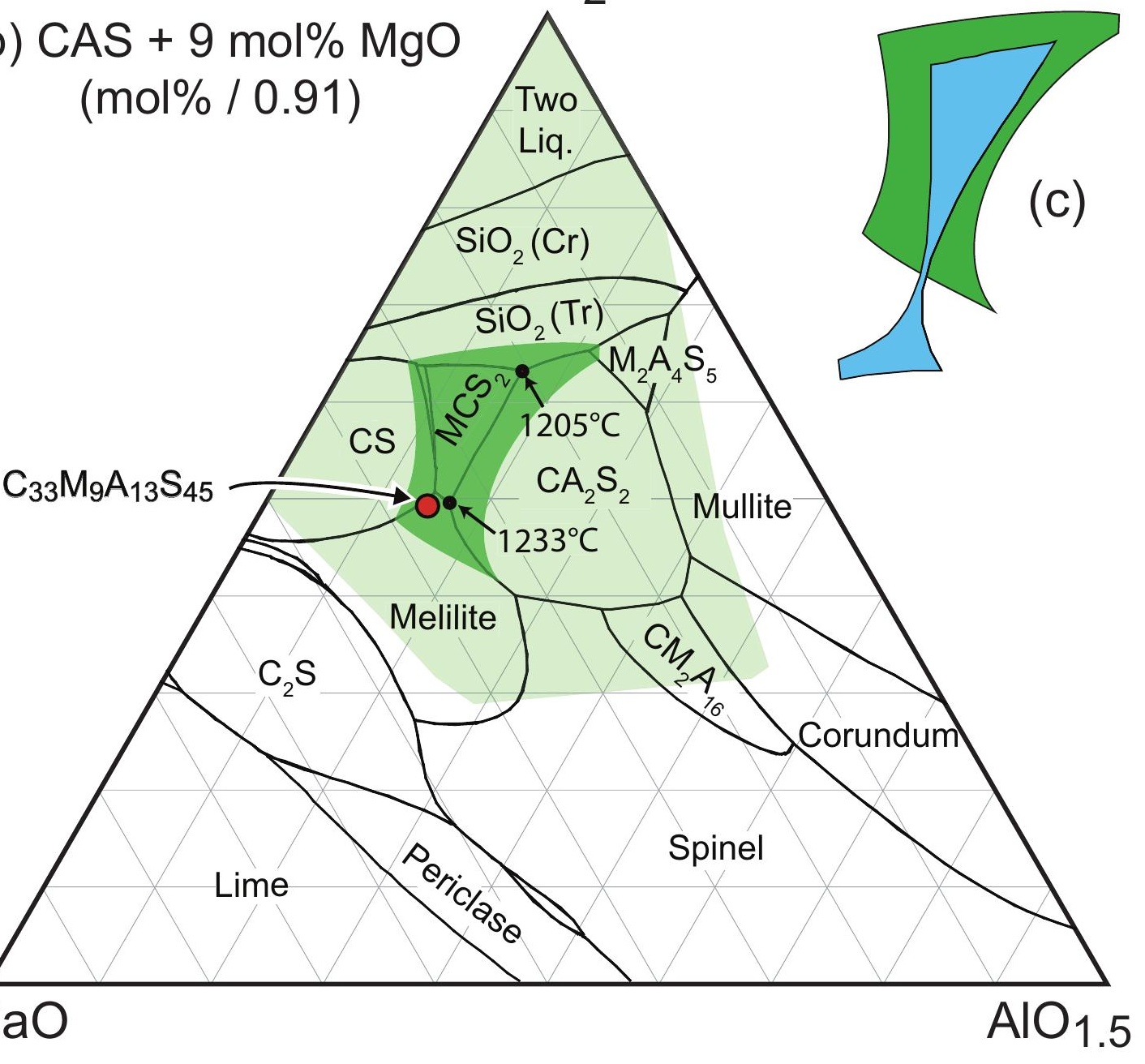


\section{$1300^{\circ} \mathrm{C} / 50 \mathrm{~h}$}

(a) $\mathrm{C}_{33} \mathrm{M}_{9} \mathrm{~A}_{13} \mathrm{~S}_{45}$ [1.4]

(b) $\mathrm{C}_{36} \mathrm{~A}_{14} \mathrm{~S}_{50}$ [1.4]

Glass

\section{Glass}

\section{$\mathrm{CaSiO}_{3}$}

(c) $\mathrm{C}_{24} \mathrm{~A}_{17} \mathrm{~S}_{59}$ [2.5]

(d) $\mathrm{C}_{15} \mathrm{~A}_{15} \mathrm{~S}_{70}[4.7]$

Glass

$\mathrm{SiO}_{2}$

Glass 


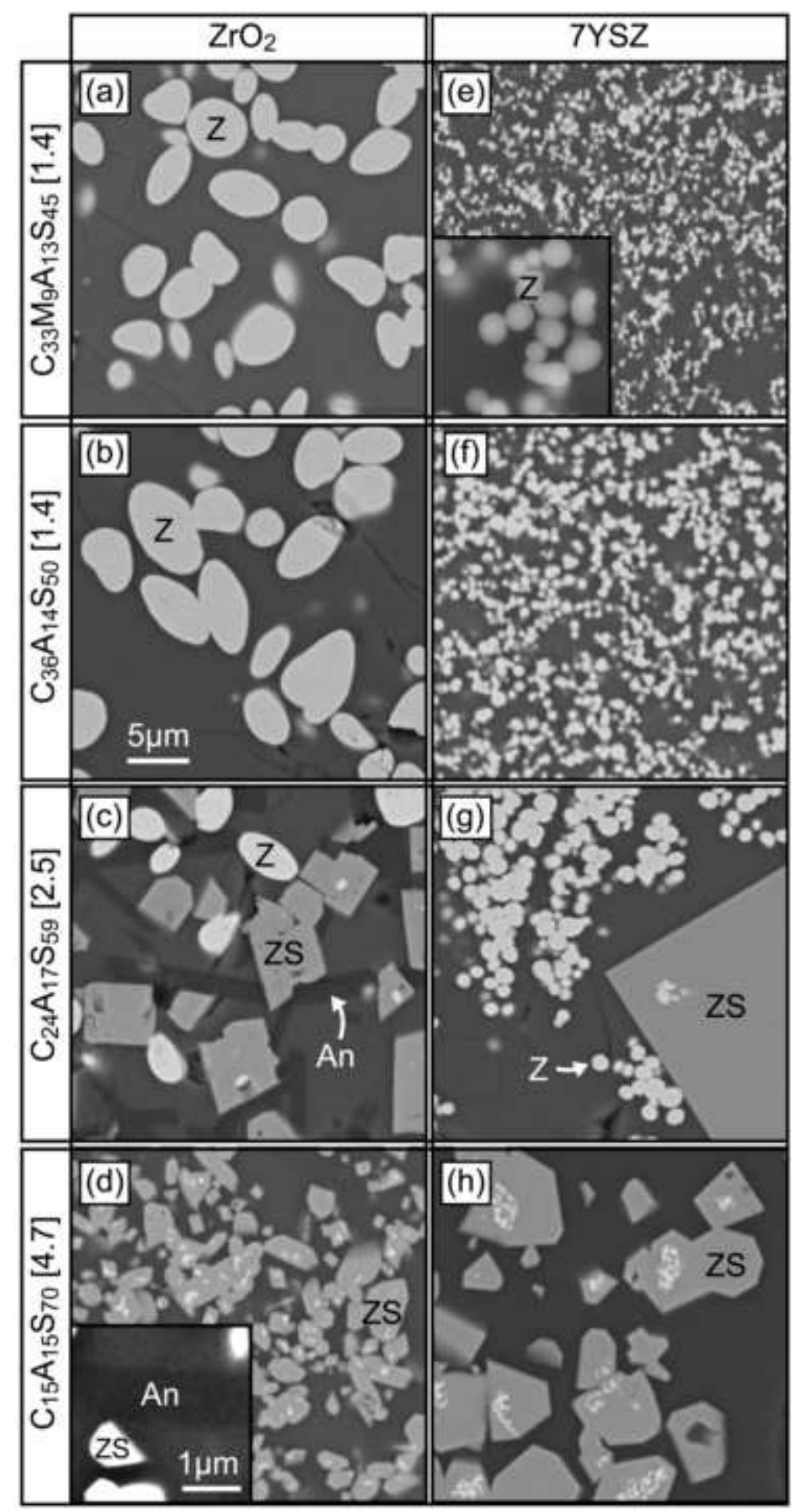

MYSZ

\section{(1)} $4,5, a$, s.

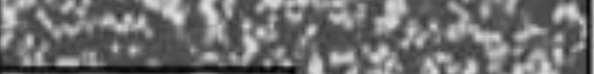
$\mathrm{Z} \quad \forall \times 5+2,2$

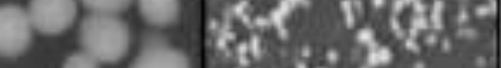
$1, x \times 4$ $18 x^{2}+y^{2}+a x$

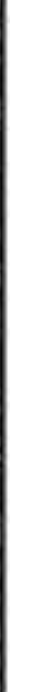
. (e) 0 . (1) 


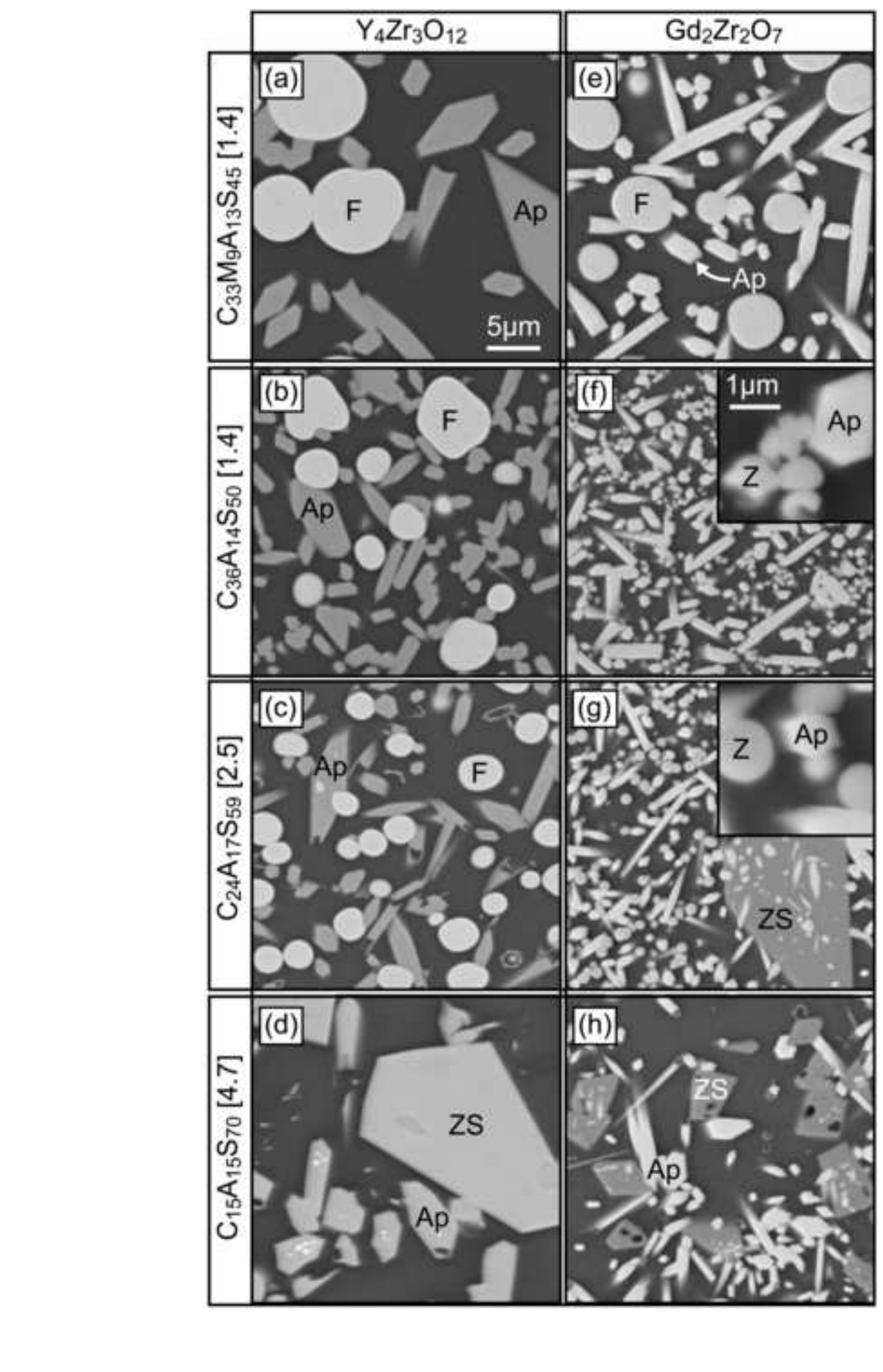

Figure 5

\section{.}


(a) $\mathrm{CaO}$ Concentration in Apatite

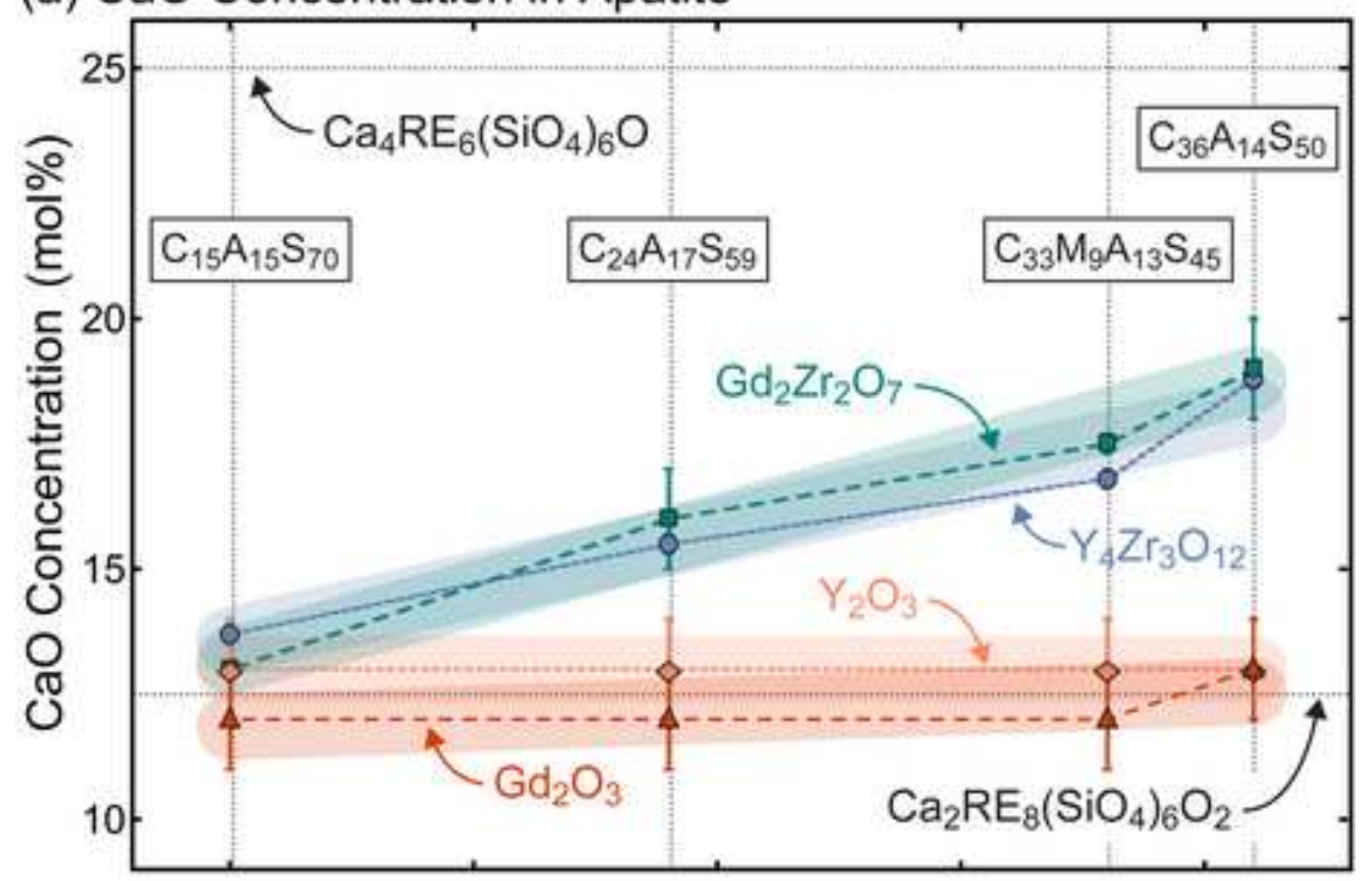

(b) $\mathrm{ZrO}_{2}$ Concentration in Apatite

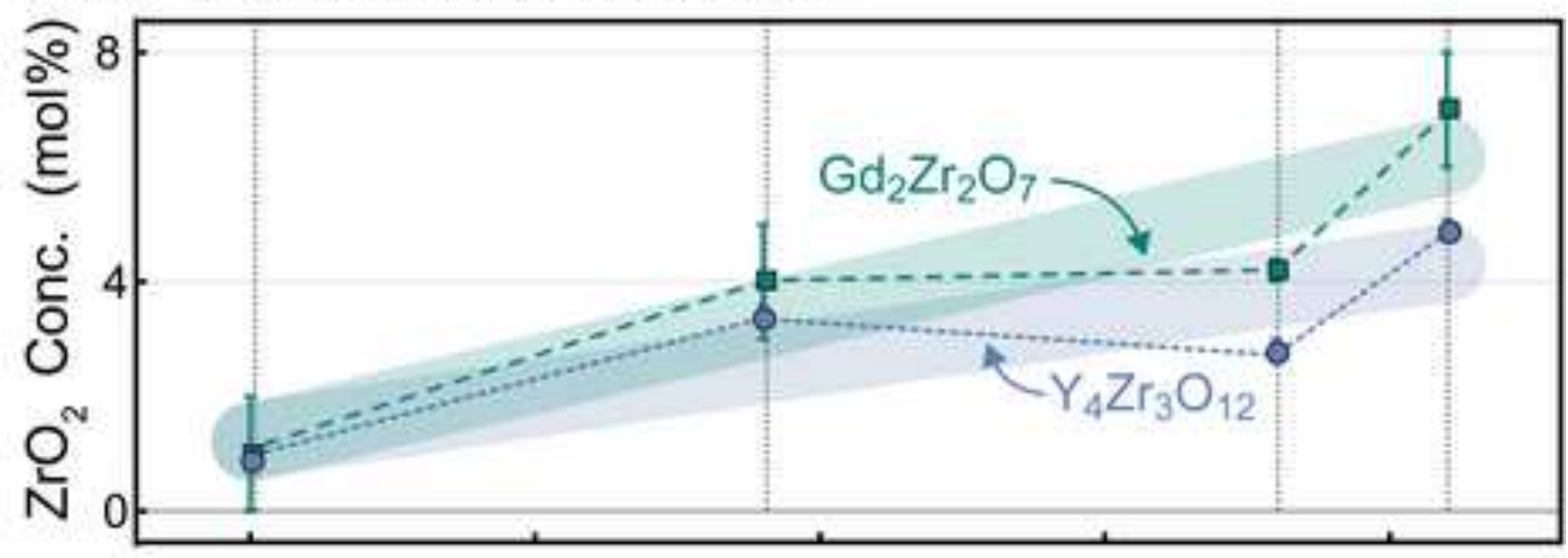

(c) Calculated Oxygen Atoms per Apatite Formula Unit

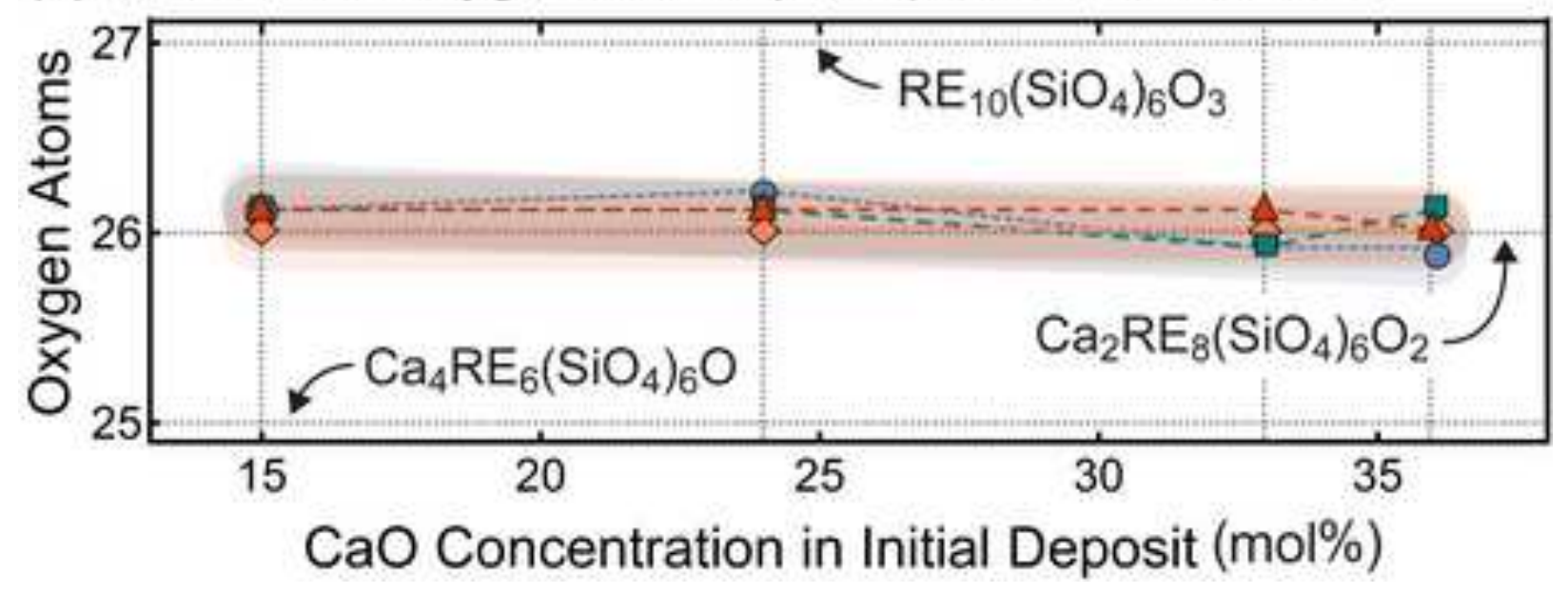




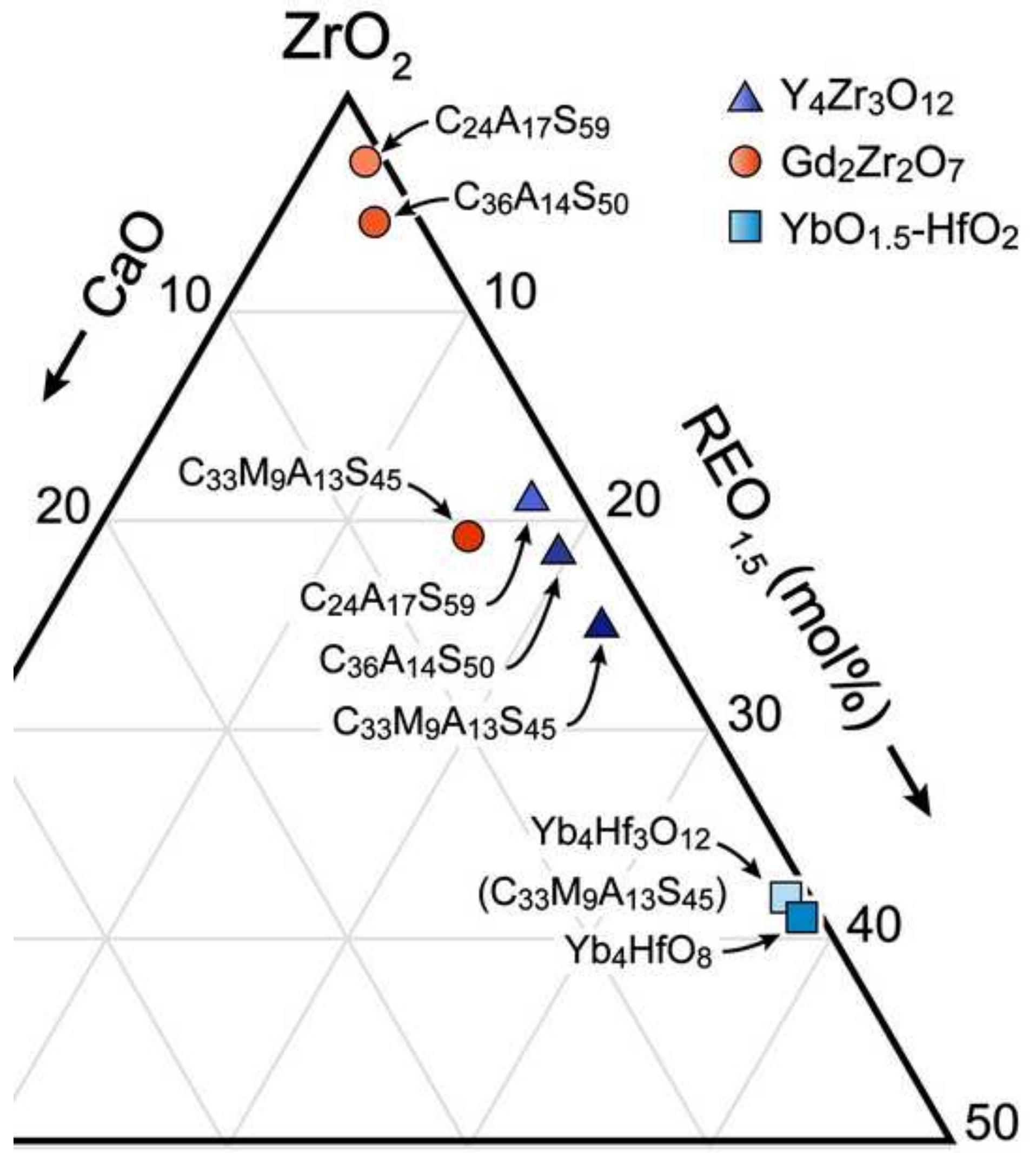




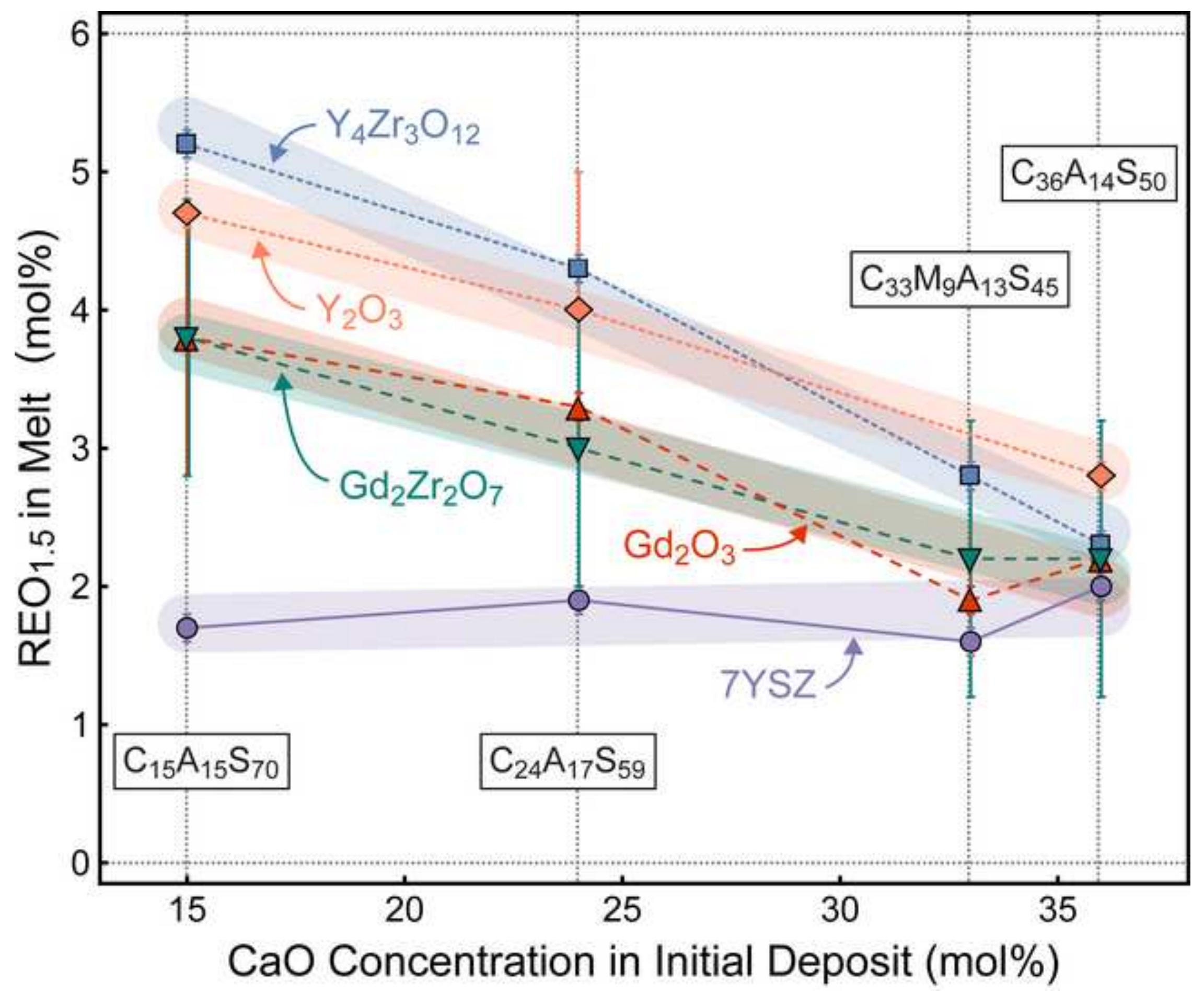



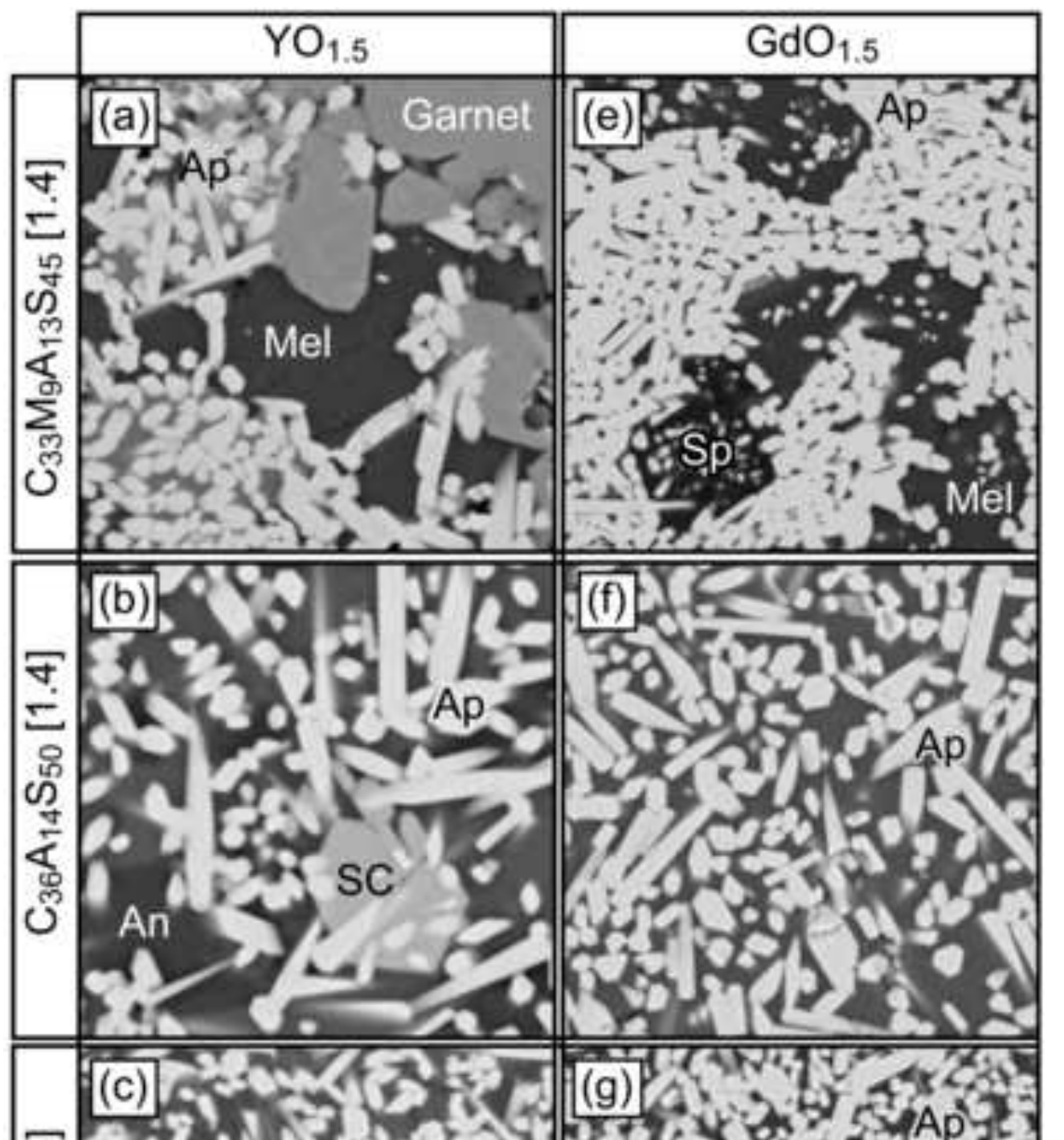

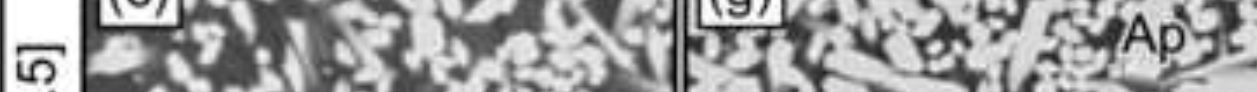

군

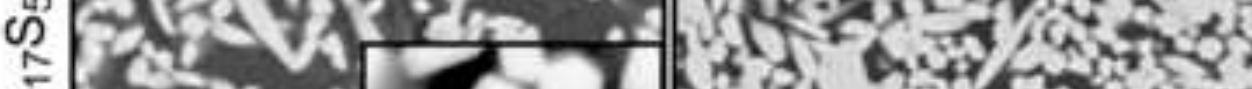

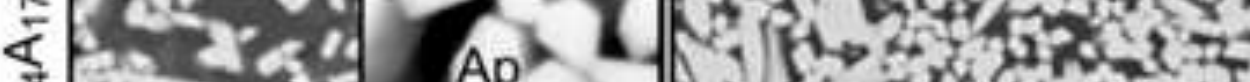

चे $A p$ A

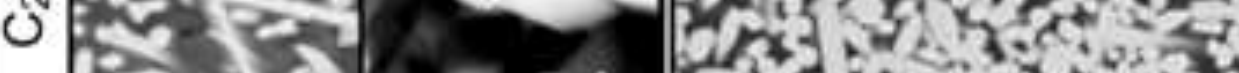

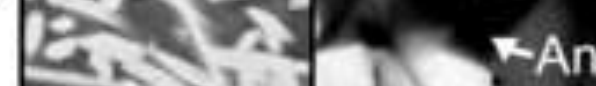

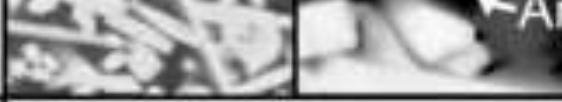

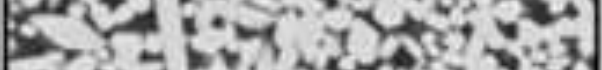
anthisus

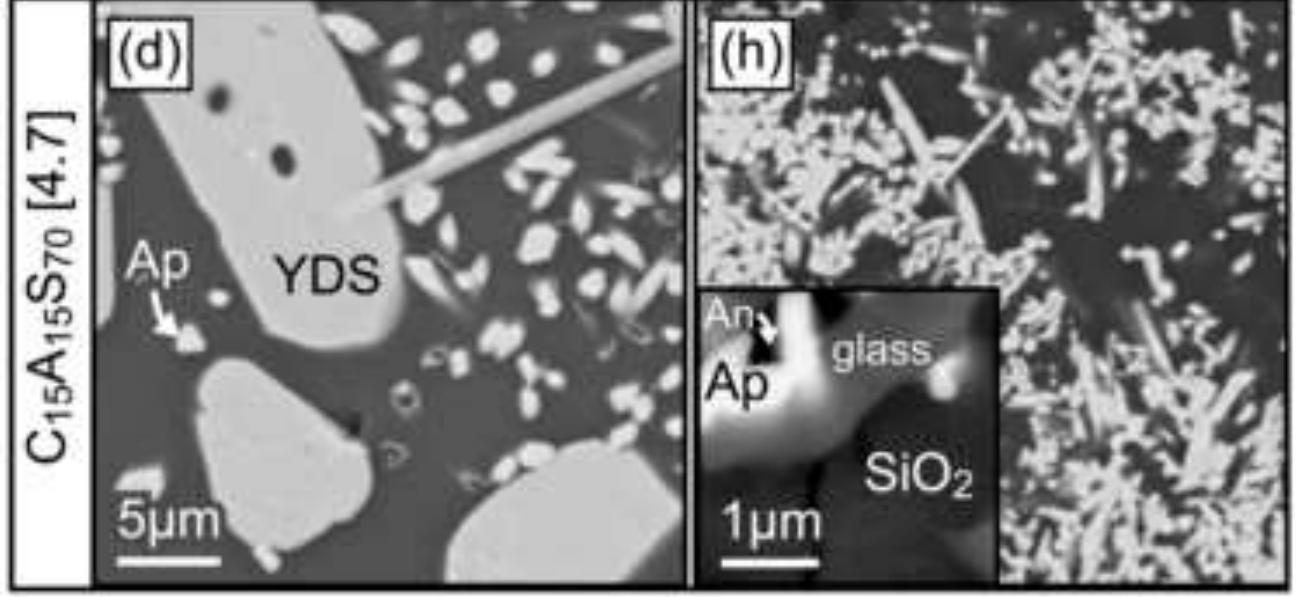




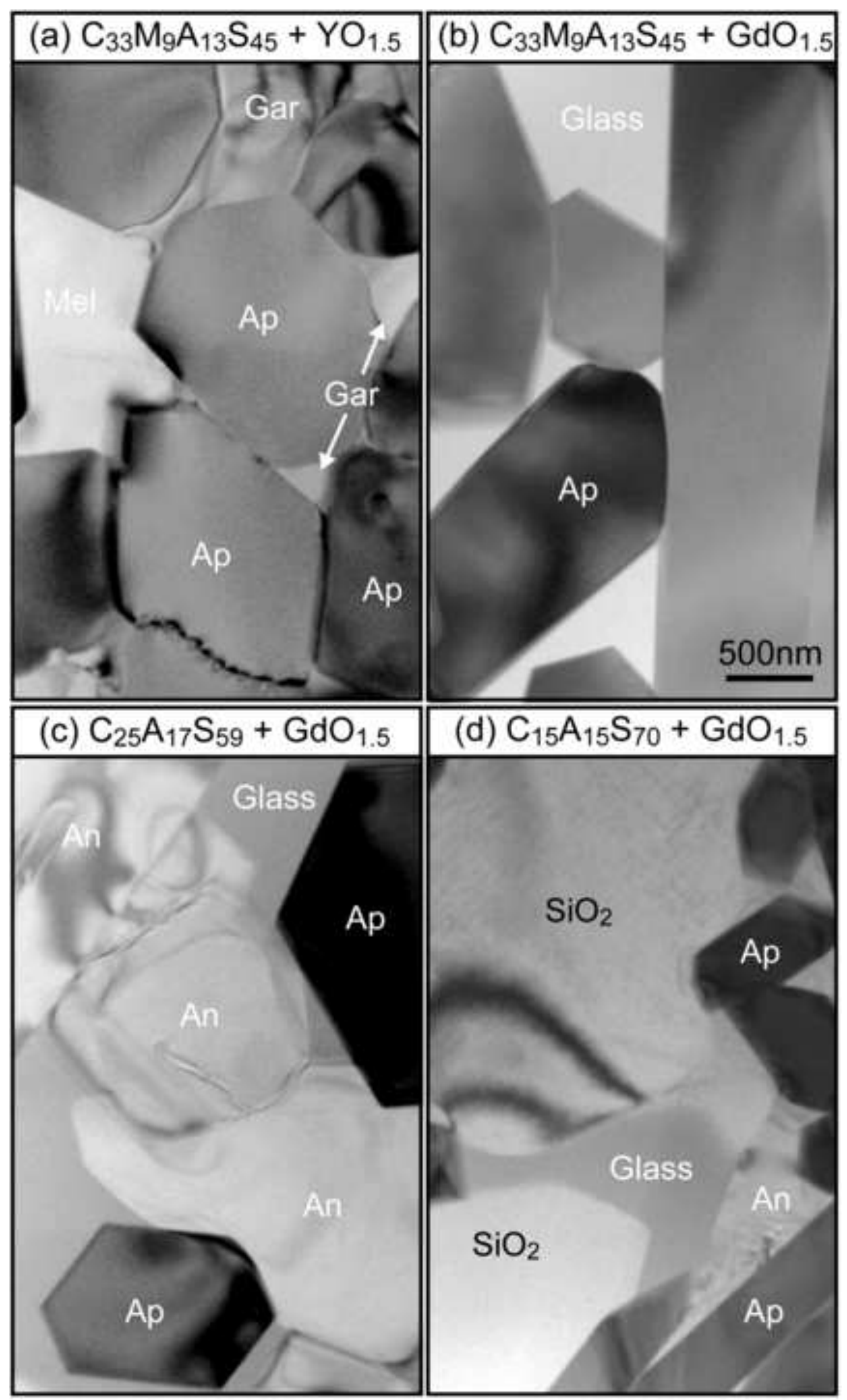


(a) $\mathrm{SiO}_{2}$ Concentration in Residual Melt

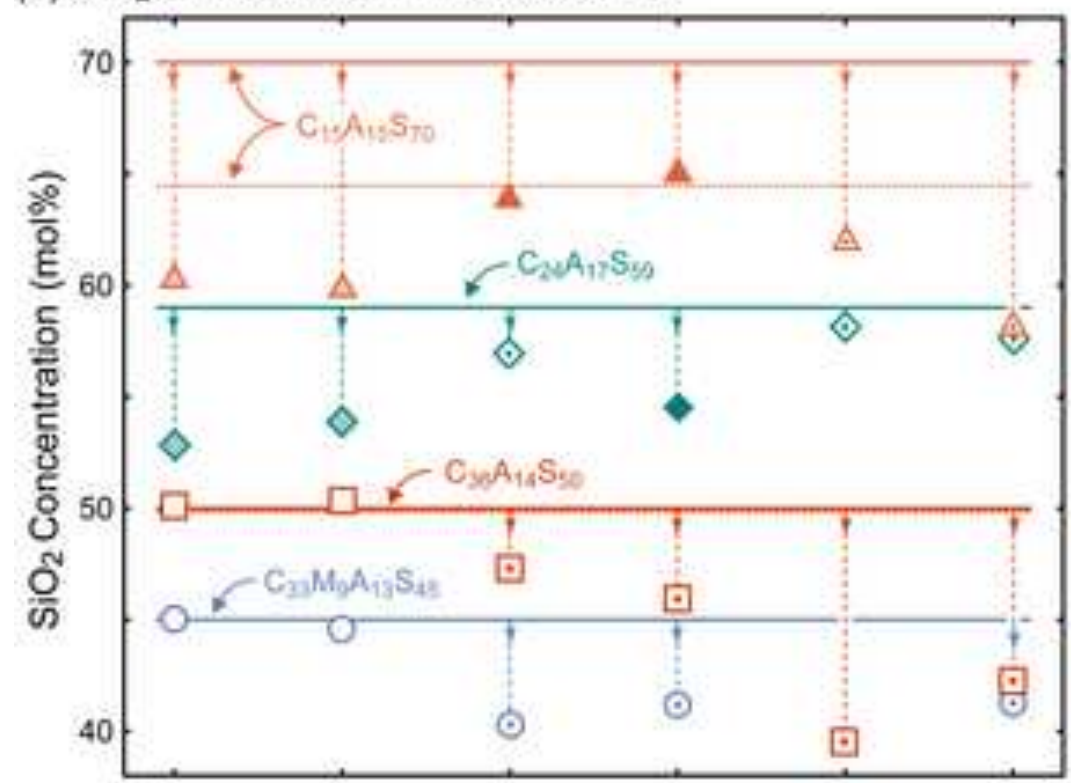

(b) Molar Si:Ca Ratio in Residual Melt

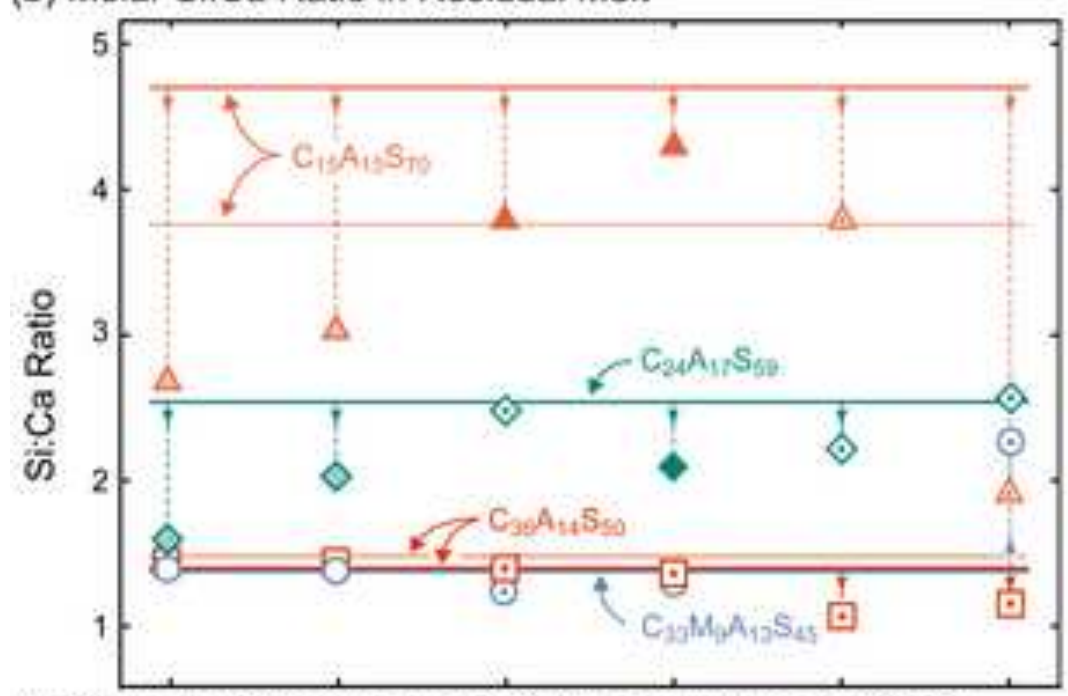

(c) Calculated Viscosity of Residual Melt (excl. Zr, Y, Gd)

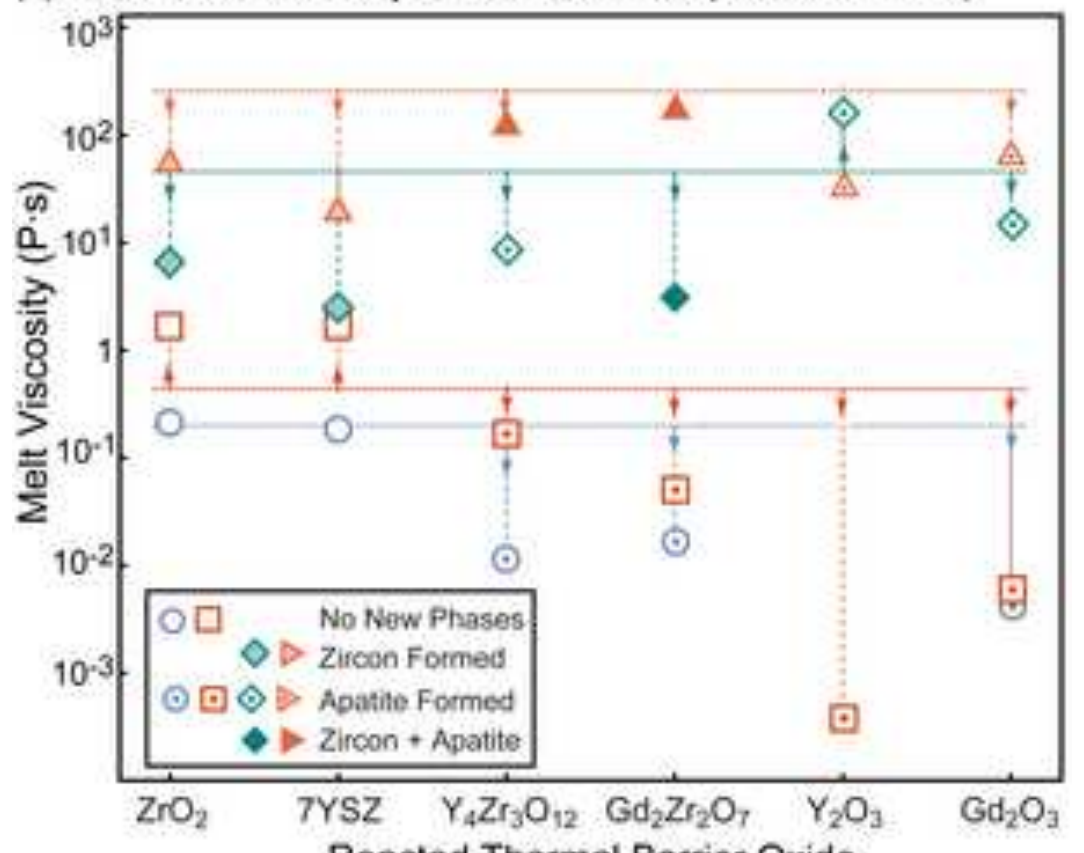

Reacted Thermal Barrier Oxide 

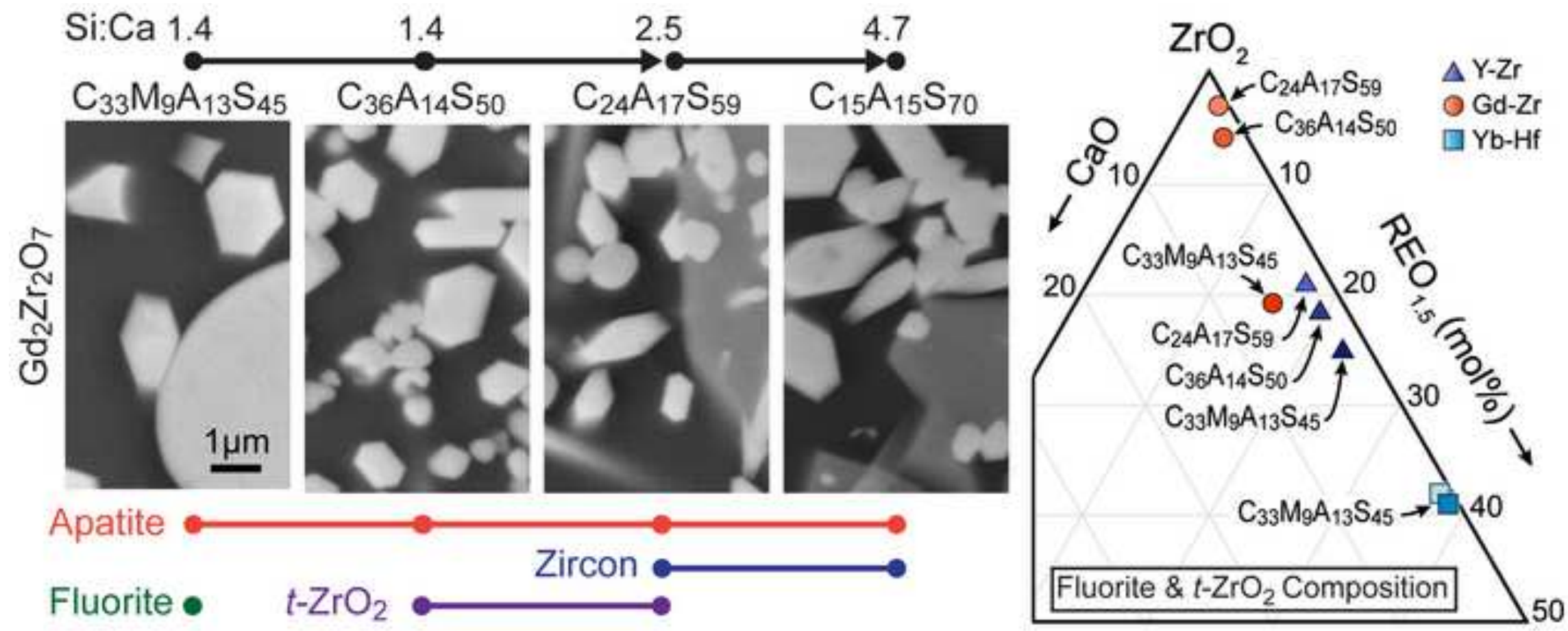